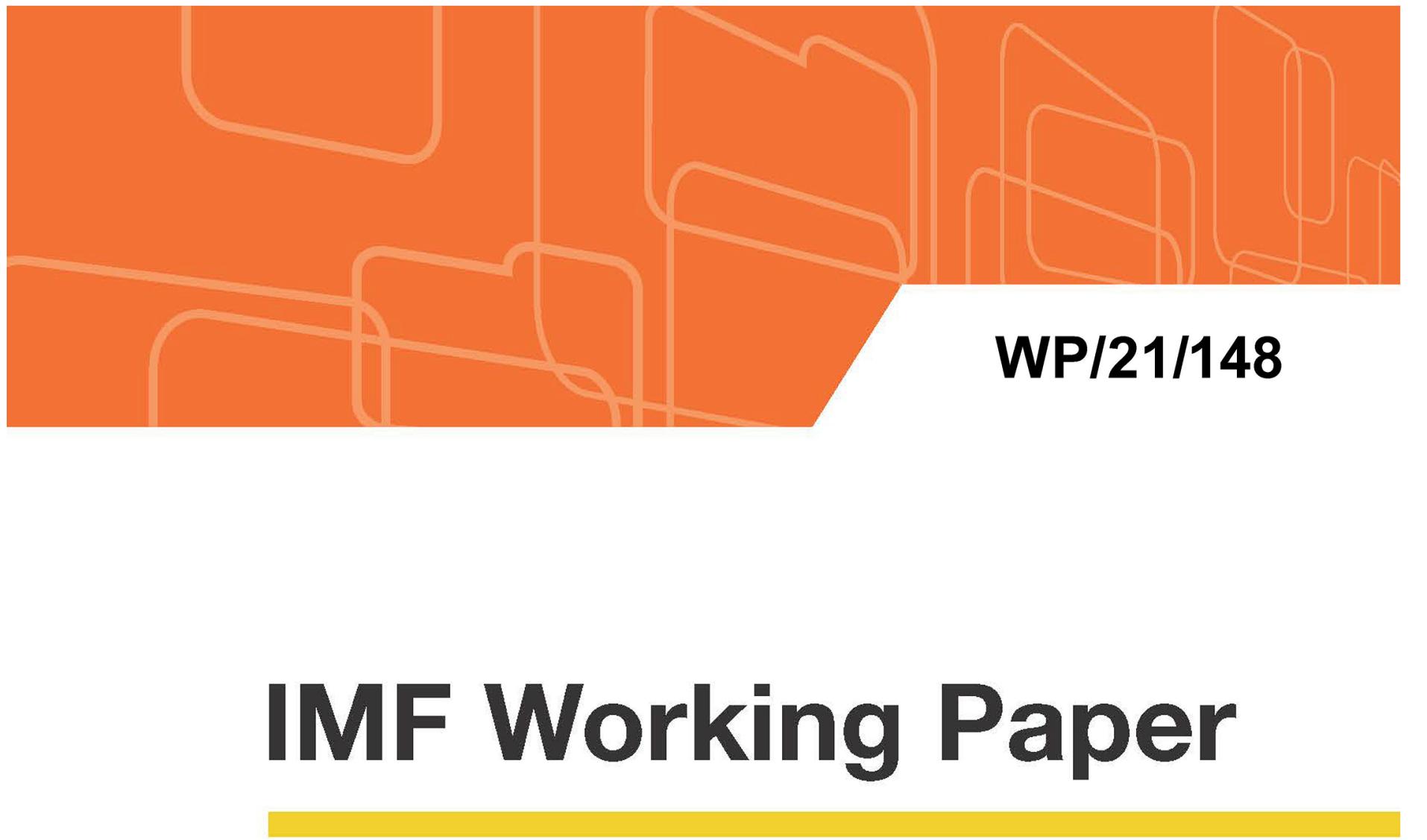

\title{
Chile: A Role Model of Export Diversification Policies?
}

by Gonzalo Salinas

IMF Working Papers describe research in progress by the author(s) and are published to elicit comments and to encourage debate. The views expressed in IMF Working Papers are those of the author(s) and do not necessarily represent the views of the IMF, its Executive Board, or IMF management. 


\title{
IMF Working Paper
}

Western Hemisphere Department

\section{Chile: A Role Model of Export Diversification Policies?}

Prepared by Gonzalo Salinas ${ }^{1}$

Authorized for distribution by Sònia Muñoz and Luca Ricci

May 2021

IMF Working Papers describe research in progress by the author(s) and are published to elicit comments and to encourage debate. The views expressed in IMF Working Papers are those of the author(s) and do not necessarily represent the views of the IMF, its Executive Board, or IMF management.

\begin{abstract}
Largely because of its vast copper reserves, Chile's exports are highly concentrated on this low complexity product and this is often cited as a major drawback of its economic policy framework. However, its exogenous copper abundance conceals the country's success in developing non-mineral and complex exports. This achievement is remarkable considering its remoteness from the large international economic centers, which limits its integration to global value chains. As suggested in this paper, this accomplishment reflects Chile's strength in policy areas that foster non-mineral exports (including complex exports), making the country a role model in export diversification and complexity policies among emerging market countries.
\end{abstract}

JEL Classification Numbers: F1, O1, O4

Keywords: International trade, economic growth, economic development, export diversification, export complexity.

Author's E-Mail Address: gsalinas@imf.org

\footnotetext{
${ }^{1}$ Thanks to Tang Li and Luiggi Silva for excellent research a ssistantship, and to Reda Charif, Metodij HadziVa skov, Samuel Pienknagura, Luca Ricci, and Karim Youssef for their ex tremely valuable comments.
} 


\section{A. Introduction}

Although strong economic fundamentals have allowed Chile to experience economic growth and poverty reduction on par with East Asian countries, there is a perception that the country has underperformed in terms of promoting export diversification and structural transformation. This paper documents how such a perception is incorrect because, even though it is factually correct that Chile has an export basket highly concentrated in copper products, it has considerably developed non-hydrocarbon/mineral (NHM) exports, including of complex products (as defined in Hidalgo and Hausmann, 2009).

This is of particular importance as developing other more labor-intensive export sectors (such as manufacturing and services) could have more direct social benefits than copper. Moreover, there is evidence that export diversification could further enhance Chile's long term economic growth as a more diversified export basket is empirically associated with lower output volatility (see for example Haddad and others, 2010), and that the latter is associated with higher long-term output growth (Ramey and Ramey, 2005; Hnatkovska and Loayza, 2003; Haddad 2012). To the extent possible, it would be desirable to expand export in products with high value-added as this, by definition, would more effectively increase domestic income.

Enduring dependence on copper exports leads many to suggest that the economic approach the country has taken in recent decades needs to be substantially overhauled as it has proved inconsistent with structural transformation and export diversification. However, this paper shows that Chile has exceled in the development of NHM exports, including those of high complexity. Chile's traditional indicators of export diversification and complexity are not favorable, reflecting its exogenous abundance of copper and high international copper prices, not the country's ability to develop non-copper exports. The paper further shows that Chile's positive performance in developing other exports is in line with the strength of its determinants of export diversification and complexity (as identified in other studies), which has helped the country to gradually offset the disadvantage imposed by its remoteness to large international markets. In fact, controlling for the negative effect of remoteness, Chile's per capita exports of NHM and complex exports are among the highest in the world.

Section B assesses Chile's progress in developing export categories that lead to diversification and complexity, revealing a much more positive view than when looking at commonly used indices of export diversification and complexity. Section C shows how Chile exports significantly more of these products than predicted by its distance from the main international markets and how adding its relatively strong vector of policies remarkably sharpens the prediction. An analysis of Chile's export development over the last four decades shows this country has offset its remoteness through strong economic fundamentals, with a strong governance and remarkable trade policy openness being key contributors more recently. Section E presents concluding remarks. 


\section{B. Revisiting the progress towards export diversification and complexity}

Traditional quantitative measures of export concentration are high for Chile relative to the average in other Emerging Market regions, evidence of its strong dependence on copper exports (copper represents about half of Chile's goods exports). With a HerfindahlHirschman index of exports concentration above 0.3 in 2015 , Chile's export basket appears less diversified than those of manufacturing powerhouse countries of Central America and Mexico (CAM), and East Asian Emerging Markets (EAEM).
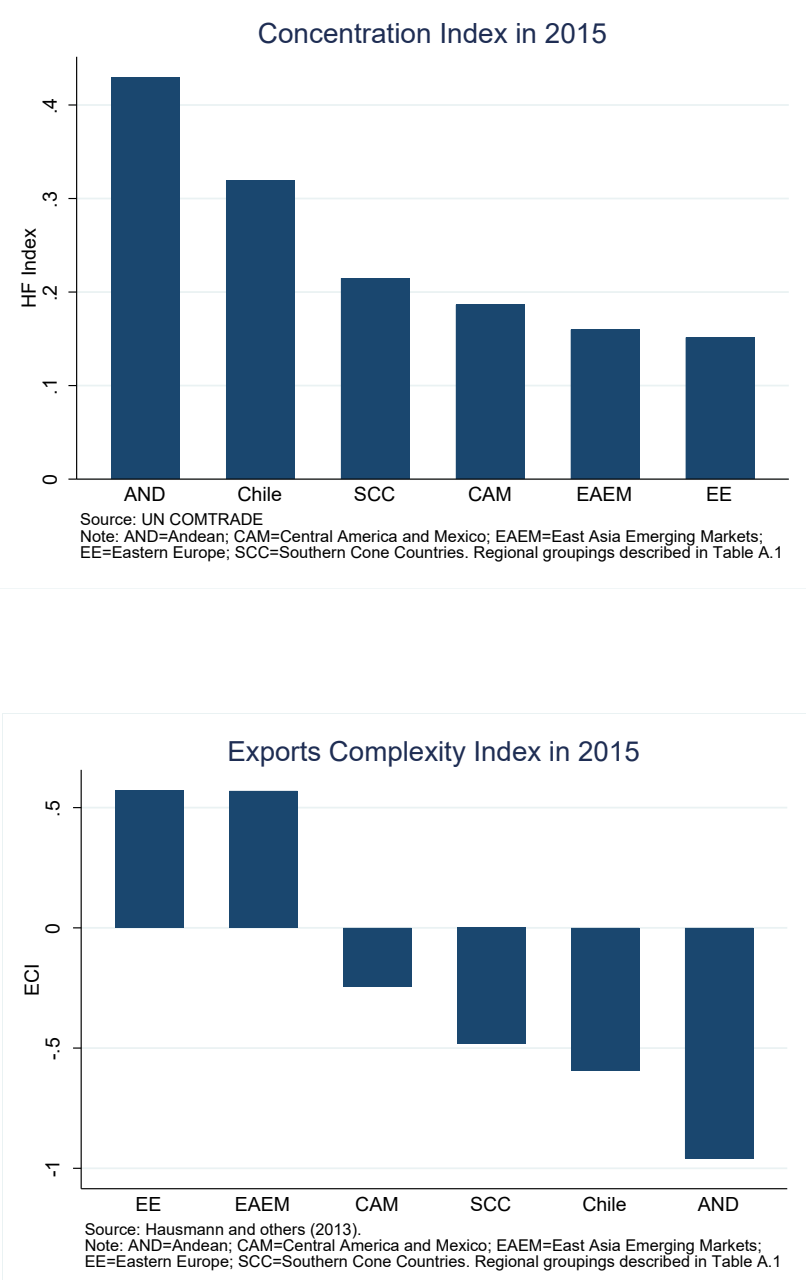

Also, partly because of copper dominance, Chile ranks low in the Economic Complexity Index (ECI). ${ }^{1}$ Since copper appears in the bottom 5 percent of the Product Complexity Index (Hausmann and others, 2013), Chile's ECI is lower than in most other Emerging Market regions. This is the case although Chile performs strongly in factors that are statistically related to exports diversification and complexity identified in Giri and others, (2019), Ding and Hadzi-Vaskov (2017), and Salinas (2021) such as educational attainment, institutional strength, and infrastructure development.

\footnotetext{
${ }^{1}$ The ECI of a country is calculated in Hidalgo and Hausmann (2009) based on the diversity of exports a country produces and their ubiquity, or the number of the countries able to produce them (and those countries' complexity). According to its authors, this index aims to measure the productive capabilities and knowledge in a society as expressed in the products it exports.
} 
After the copper boom started in the early 2000s, Chile's exports have become more concentrated and its ECI dropped considerably. However, the fall in Chile's ECI seems at odds with the sustained productivity growth that Chile has experienced in recent decades which, a priori, should have increased Chile's capacity to produce more complex exports. This decline can be explained by the fact that the ECI falls when a product of low complexity such as copper, increases its share in the export basket, and the value of exported Chilean copper substantially increased during the international commodity boom of the early $2000 \mathrm{~s}^{2}$ This shows how ECI fluctuations can be related to factors other than an economy's capacity to produce complex products, such as movements in commodity prices.
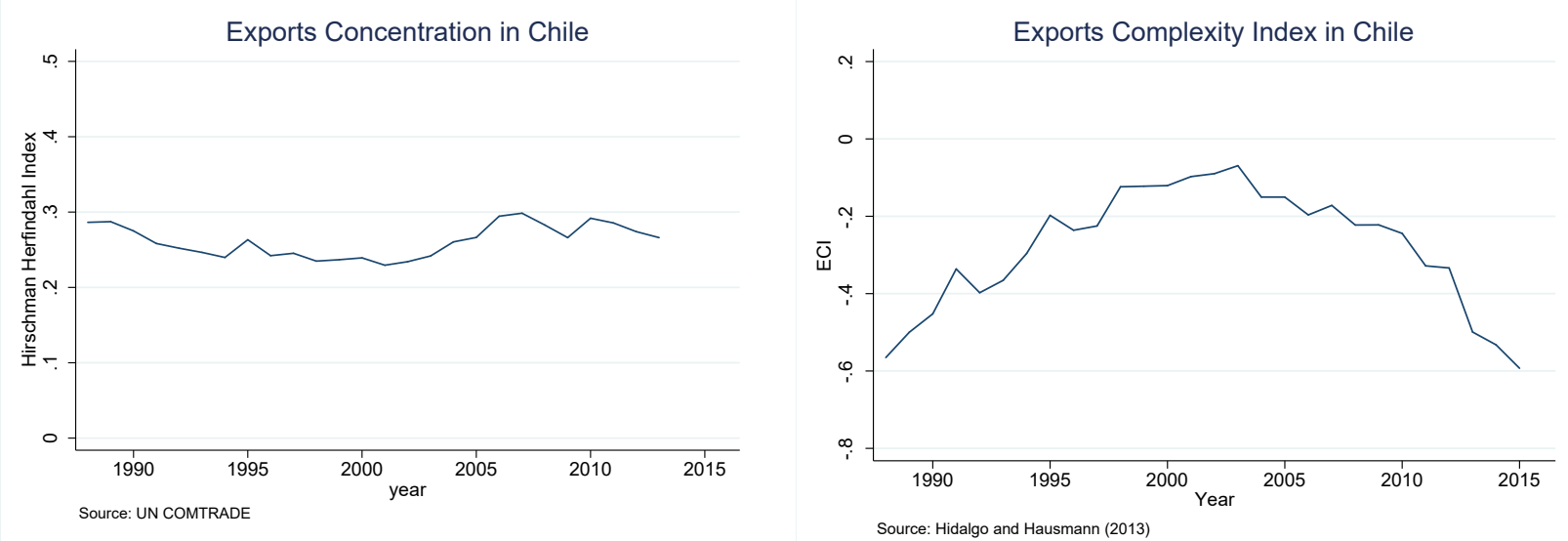

To better assess Chile's progress in promoting diversification and enhancing export complexity, one must go beyond commonly used indices of diversification and complexity. As discussed in Salinas (2021) and as seen in Chile in the early 2000s, export concentration indices in commodity exporters are affected by exogenous changes in commodity export volume and price, hence not purely reflecting the evolution of the NHM exports that can lead to diversification and complexity. Simlarly, the levels and changes in the ECI in commodity exporting countries may not fully reflect countries' capacity to produce complex products.

\footnotetext{
${ }^{2}$ Notably, copper exports grew from US\$ 8 billion in 2003 to a peak of US\$ 54 billion in 2011 , when it accounted for 54 percent of Chile's goods exports.
} 
This disconnect is striking when comparing the ECIs of Australia and Chile with those of Honduras and El Salvador. Despite the higher productivity in the former two countries, as implied by their technological readiness, their ECIs are considerably below those in the latter two countries. The picture substantially changes when looking directly at the value of complex exports (those with Product Complexity Index above zero acording to Hausman and others, 2013) divided by population as suggested in Salinas (2021). The amount of complex exports per capita is less affected by exogenous natural resource abundance or fluctuations in commodity exports, variations clearly unrelated to the productive capabitlities and knowledge in a society that the ECI seeks to measure. ${ }^{3}$ Unlike the ECI, the complex exports per capita ratio is higher in the countries with higher technological readiness. ${ }^{4}$
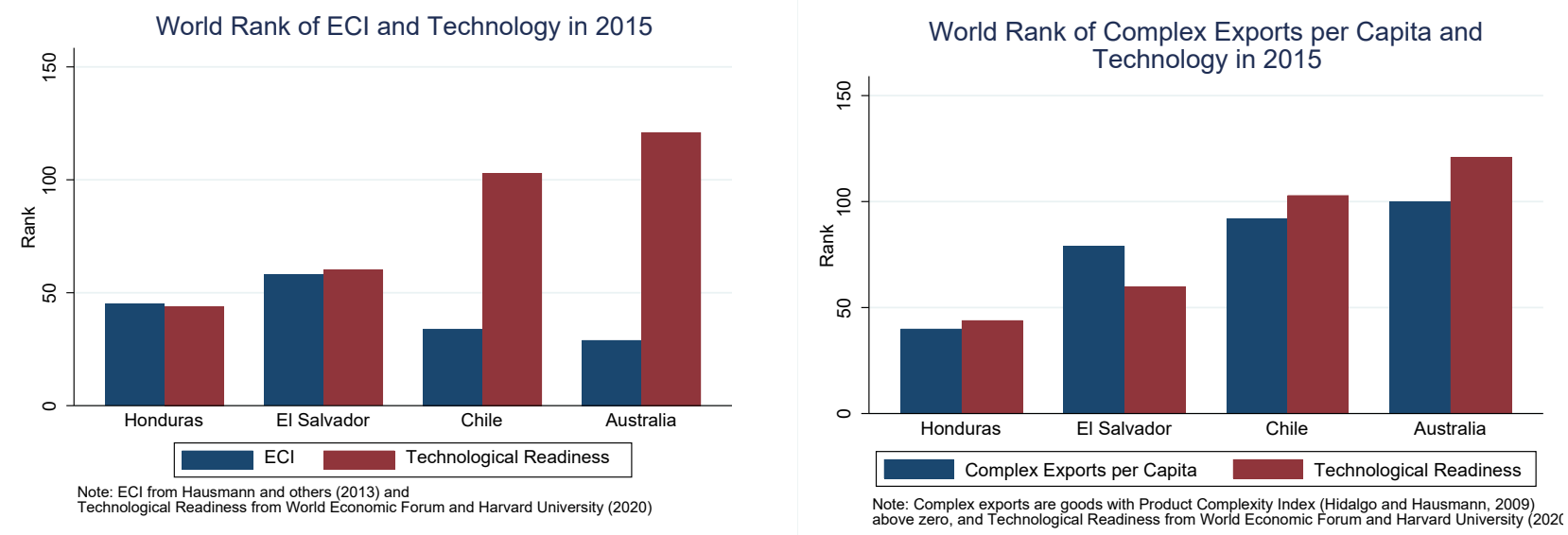

Chile's development of NHM and complex exports is more evident when focusing directly on the level and evolution of those types of exports. The growth rates of these export categories in Chile have been persistently high since the mid-1980s, in line with the productivity growth of its overall economy, and without a significant interruption during the commodity boom years since the 2000s. This continued growth indicates that the copper boom did not notably curb NHM or complex exports as would be expected from a Dutch Disease perspective. ${ }^{5}$

\footnotetext{
${ }^{3}$ As suggested in Salinas (2021), focusing on complex exports per capita rather than on the ECI is particularly useful for identification of policy determinants of exports complexity because non-policy related developments in the commodities markets can substantially influence the ECI but not the complex exports per capita (or per worker).

${ }^{4}$ The upper half of PCI includes products with a PCI above 0 . Similar results as those described in this paper are observed when focusing on products with PCI above 1 (about a quarter of all tariff lines) or when focusing on complex exports per worker instead of complex exports per capita. Note that complex exports per capita measure neglects intra-temporal and cross-country variations in the average PCI of each country. An alternative approach that would capture PCI heterogeneity and filter out exogenous commodity related developments would be to calculate the average PCI only for NHM exports. However, that would not a be an accurate measure of complexity (productive capability of a society) as it does not give a sense of the scale of complex exports production. Hence, countries with a small share of complex products that have a high PCI would appear more complex than countries with a large share of complex products but with a lower average PCI, no matter how minuscule the share of complex products would be.
}

${ }^{5}$ Figure Panel A.1 charts compare the growth of Chile's complex exports with those of selected Latin American countries. 
Chile

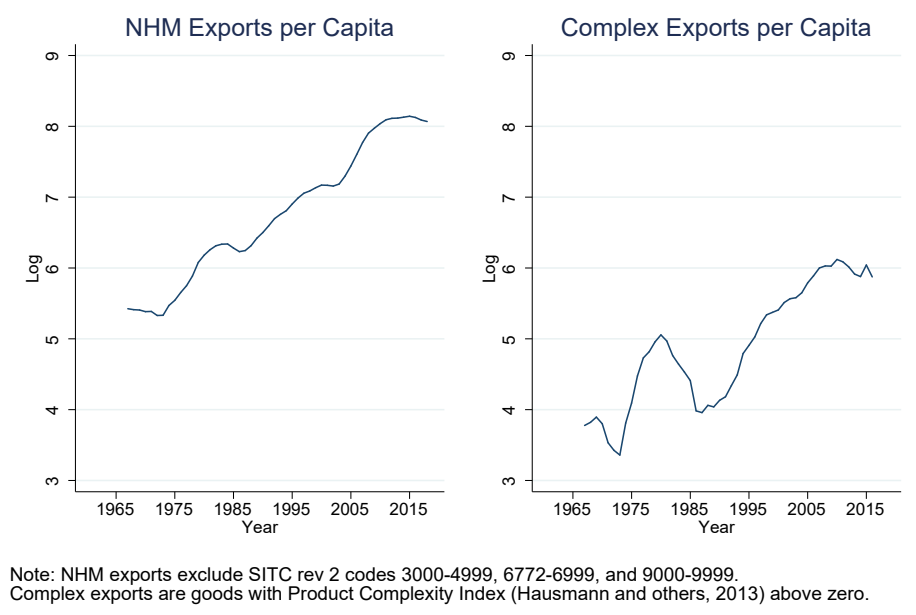

In fact, the growth rate of Chile's complex exports per capita is not too different from the average in emerging market regions with successful manufacturing export sectors (see charts below). Growing by a factor of eight in the last three decades since the mid-1980s, Chile's complex exports per capita performance has been more similar to the average in CAM and EAEM countries, than to nearby Andean (Bolivia, Colombia, Peru, and Venezuela) and Southern Cone (Argentina, Brazil, Paraguay and Uruguay) subregions, which increased exports complexity by factors of two and three, respectively. ${ }^{6}$ Thus, by 2014-16 Chile's complex exports per capita were six times higher than in Andean countries (AND) and three times higher than in the average in other Southern Cone countries (SCC).

Complex Exports per Capita in Chile and Comparators
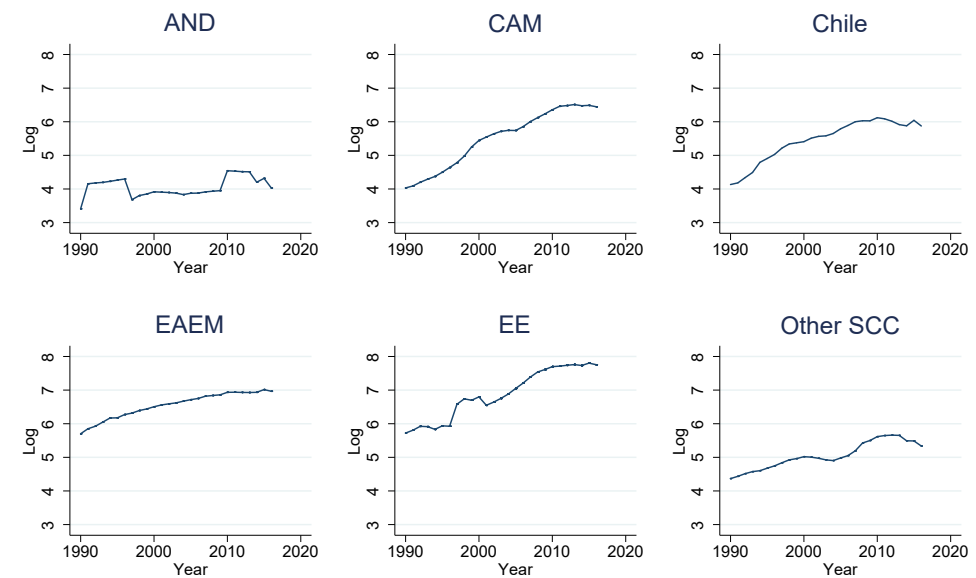

Note: $A N D=A n d e a n ; C A M=C e n t r a l$ America and Mexico; EAEM=East Asia Emerging Markets; $\mathrm{EE}=$ Eastern Europe; $\mathrm{SCC}=$ Southern Cone Countries. Regional groupings described in Table A.1

\footnotetext{
${ }^{6}$ Besides Central American countries (Costa Rica, Guatemala, Honduras, Nica ragua, and El Sa lvador)CAM includes Mexico. EAEM includes China, Indonesia, Malaysia, Thailand, and Vietnam.
} 
Following its success in developing non-copper export products in recent decades, Chile's NHM exports per capita now compares favorably to those of the manufacturing powerhouse regions of CAM and EAEM. However, because some of Chile's NHM exports are of natural resourcebased products with low complexity, the country considerably lags CAM and EAEM in terms of complex exports per capita.

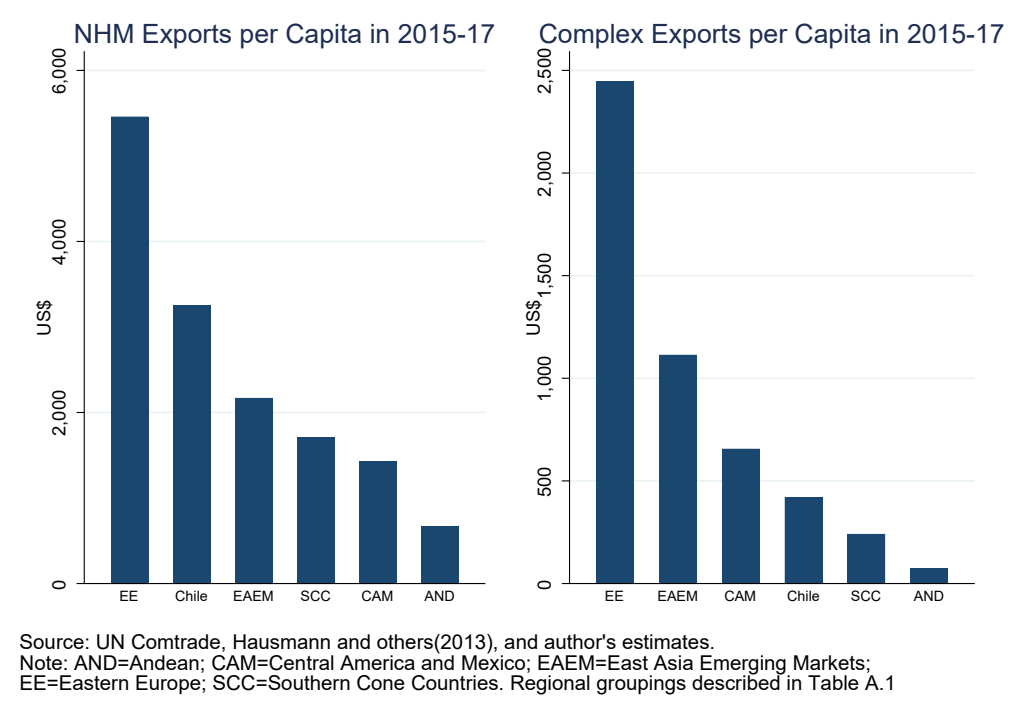

At least two methodological issues help explain CAM's and EAEM's higher complex exports per capita. One is that even though the production of copper is not particularly labor-intensive, the share of labor it demands directly and indirectly is not negligible. With less labor force available to non-copper sectors, the per capita level of complex exports is expected to be lower than in the absence of such large copper production. CAM countries do not have significant HM exports and although EAEM countries also have significant HM exports per capita, in 2017, Chile had a ratio about four times higher.

A second issue is that CAM and EAEM countries participate more intensively in GVCs than Chile, so that their gross NHM exports overstate their domestic value added. According to the OECD Trade in Value Added (TIVA) database (OECD, 2019), in 2018 the domestic value added of NHM exports of Mexico, Malaysia and Thailand, the CAM and EAEM economies with highest complex exports per capita, was around 60 percent. ${ }^{7}$ In comparison, the domestic value added of NHM exports of distant Australia and Chile was 81 and 88 percent of their gross exports, respectively. Thus, the difference in the value added of complex level per capita between EAEM and Chile is likely much lower (about 2 to 1 ) than the difference in gross complex exports per capita shown in the chart above (about 3 to 1 ).

\footnotetext{
${ }^{7}$ Data on exports value added is not a vailable formost countries, therefore the rest of thea nalysis centers on gross exports. Note that all indices of diversification and export superiority are subject to this caveat.
} 
While some of Chile's complex exports are linked to its abundant natural resources, many others are not. Looking at a list of Chile's top ten complex exports we see that only two of them, Processed Copper and Converted Paper, are products that industrialize natural resources. Most are manufacturing products, such as telecommunications products, vehicles, machinery and medicaments, that are not linked to natural resource abundance. This is a positive sign that Chile's comparative advantage is not solely related to its natural resources but also to its strength in policies that nurture export complexity (which we discuss below). Noteworthy also, Chile produces many highly complex products, with PCIs above two, such as medical equipment, electrical instruments, and metal working machine tools.

As the empirically robust gravity equation model confirms, distance is a major determinant of exports and is most likely a major hurdle for Chile's export diversification and complexity. Nevertheless, non-tourism services are less sensitive to the distance factor and this is likely why Chile's per capita exports of services compares favorably to other regions including EAEM.

Chile's service exports include those of its largest airline (the largest in Latin America), as well as Business, Information Technology, and financial services. These are skill-intensive products which show that the Chilean economy has the capabilities to produce high value-added exports especially when distance is not a major limiting factor.

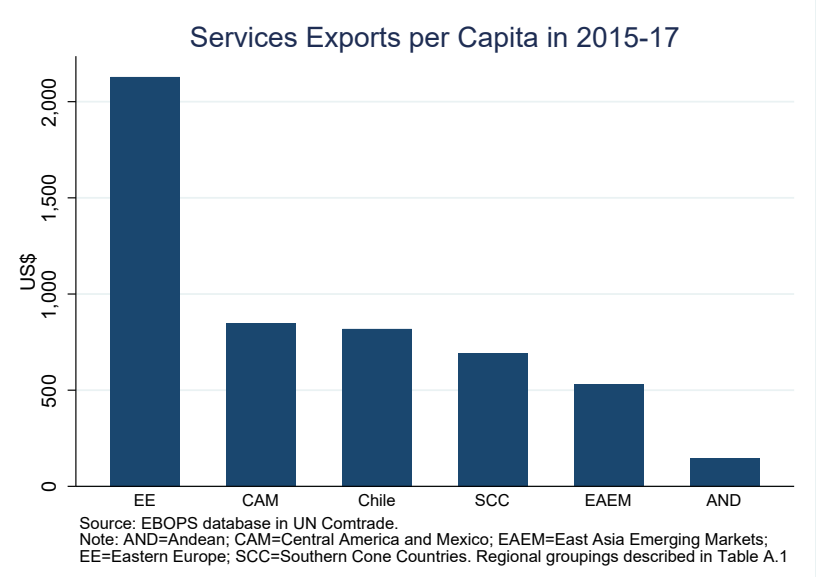

\begin{tabular}{lr}
\hline Service Exports from Chile, $\mathbf{2 0 1 6}$ & \\
\hline & US\$ m \\
\hline & \\
Transportation & 2953.0 \\
Travel & 2737.0 \\
Business services & 2525.0 \\
Computer and information services & 378.6 \\
Insurance services & 307.1 \\
Financial services & 174.3 \\
Royalties and license fees & 43.4 \\
Personal, cultural, and recreational services & 25.2 \\
\hline \multicolumn{2}{l}{ Source: EBOPS Database in UN Comtrade. }
\end{tabular}




\section{Chile's Diversification Hampered by Remoteness}

In line with the empirical international trade literature, Salinas (2021) finds that distance to international markets and standard gravity equation variables are significantly associated to export categories that can diversify the typically commodity-dependent export baskets of developing countries, such as NHM, manufacturing, and complex exports (see Table A.2). ${ }^{8}$ This is corroborated by empirical studies in the Global Value Chain (GVC) literature (for example, Cadestin and others, 2016, and Raei and others, 2019), which conclude that gravity equation variables are key determinants of GVC participation. ${ }^{9}$

In fact, Salinas (2021) finds that a Proximity to Markets (PM) index measuring a country's geographic proximity to international markets explains on its own about a quarter of the variation in NHM, manufacturing, and complex exports per capita. ${ }^{10}$ As expected in the absence of significant transport costs, the PM index explains less of the variation of services.

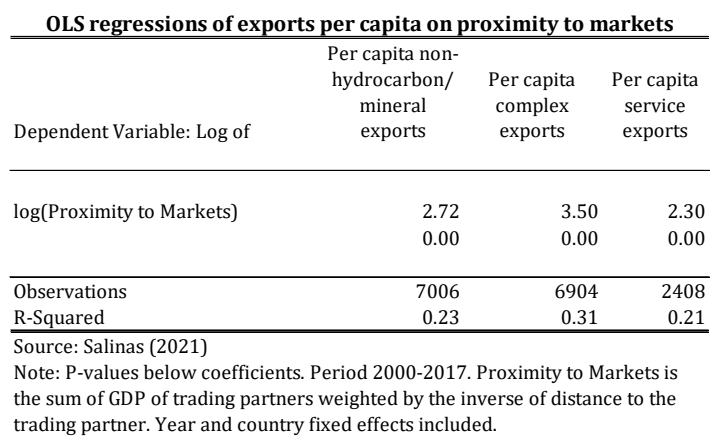

Chile's major weakness in developing complex and nonmineral exports in general is most likely its remoteness from the main centers of global economic activity. Far from the large Asian, European, and North American markets, transportation costs of Chile's exports are considerably higher than for countries that are located in the close periphery of these regions. Importantly, this limits its potential to join GVCs and therefore it is not surprising that its level of complex exports per capita is considerably lower

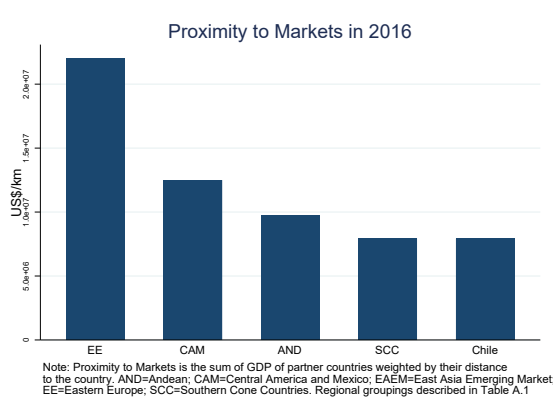
than in other regions that are closer to the major world economic centers.

\footnotetext{
${ }^{8}$ Similarly, Weldemicael (2012) finds that the Exports Sophistication index, a n index capturing the implied productivity of exported goods (Hausmann a nd others, 2006) is significantly and negatively determined by a n index of geographic remoteness. Hausmann and others (2006) methodology defines products of higher sophistication as those that a re mainly exported by higher income per capita countries.

${ }^{9}$ Also, in line with standard trade theory, Salinas (2021) finds that labor costs are negatively rela ted to exports development, including of complex exports.

${ }^{10}$ This index of Proximity to Markets is the sum ofGDP of rest of the world (ROW) countries weighted by the inverse of distance to each ROW partner (proximity to markets). Statistically proximity to markets is not only strongly a ssociated with the level of complex exports, but also to its annual growth ra te. Based on dynamic panel regression analysis, Sa linas (2021) establishes that over the la st five decades doubling a country's PM has been a ssociated with a bout ten percentage points higher a nnual growth in complex exports percapita. This estimate implies that Chile's complex exports have been growing faster than explained by its distance from international markets when compared to dynamic East Asia n exporters of complex products. Because, for example, Malaysia's PM is about 170 percent of that of Chile, Malaysia's complex exports were expected to grow seven percentage points higher than Chile's, yet the growth difference over the la st fifty years has been of 2.8 percentage points.
} 
Statistical estimates of the impact of geographic remoteness on export development in Salinas (2021), predict a large difference in complex exports per capita between Chile and less remote EM regions. For instance, as Chile's PM index is about half of the average PM of EAEM countries, these statistical estimates predict that its NHM, manufacturing, and complex exports per capita should be about a fifth of the EAEM average level.

Considerable progress towards diversification and complexity can thus be achieved by strengthening connectivity to markets. Although geographic distance is a fixed variable, "effective" proximity to markets can increase through investments in transports and communications infrastructure that lower the cost of goods and knowledge exchange. ${ }^{11}$

In addition, the empirical literature has identified several determinants of exports diversification and complexity that can help Chile offset its remoteness. Several studies (Ding and HadziVaskov, 2017; Giri and others, 2019; Salinas, 2021) statistically associate export diversification and export complexity with higher educational attainment, stronger governance and institutional development, lower barriers to trade, and higher physical in frastructure development. ${ }^{12}$

By adding these policy variables to PM, Salinas (2021) explains up to 80-90 percent of crosscountry variation in NHM and complex exports. Added-variable plots in Panel Figure A.2, show the marginal contribution of the main determinants in that study. When controlling for these variables, the PM index alone predicts that Chile's NHM, manufacturing, and complex exports per capita should be about a third of the EAEM average level.

The point-estimates for the impact of changes in policy variables on NHM, manufacturing, and complex exports are substantial. Increasing schooling attainment by one standard deviation more than doubles these exports; enhancing governance by one standard deviation increases them by 35 percent; improving infrastructure by one standard deviation increases them by 30 percent; and cutting tariffs from 15 to 5 percent increases them by almost 50 percent.

Scatter plots showing complex exports per capita predicted by the PM index in Salinas (2021) versus their actual level indicates that Chile exports more of these products than expected given its remoteness (see chart below). This suggests that Chile's policies have helped it offset its distance disadvantage. In general, all countries that are significantly above the fitted line very

\footnotetext{
${ }^{11}$ Proximity to markets can also increase with higher GDP of nearby trading partners, but this is of course largely out of control of local policy makers.

${ }^{12}$ Population data in this paper is Total Population in World Bank's World Development Indicators. Governance is approximated by World Bank's Worldwide Governance Indicators, Education by the United Nations' Human Development Report Education Index, which is an average of mean years of schooling and expected years of schooling. Infrastructure by the World Economic Forum's Global Competitiveness Report 12th pillar. Tariff is the simple average tariff in the World Bank's World Integrated Trade Solution.
} 
likely have strong export development policy frameworks that allow them to surpass expectations anchored in geographic determinants and therefore hint at "role models" of export development policies.

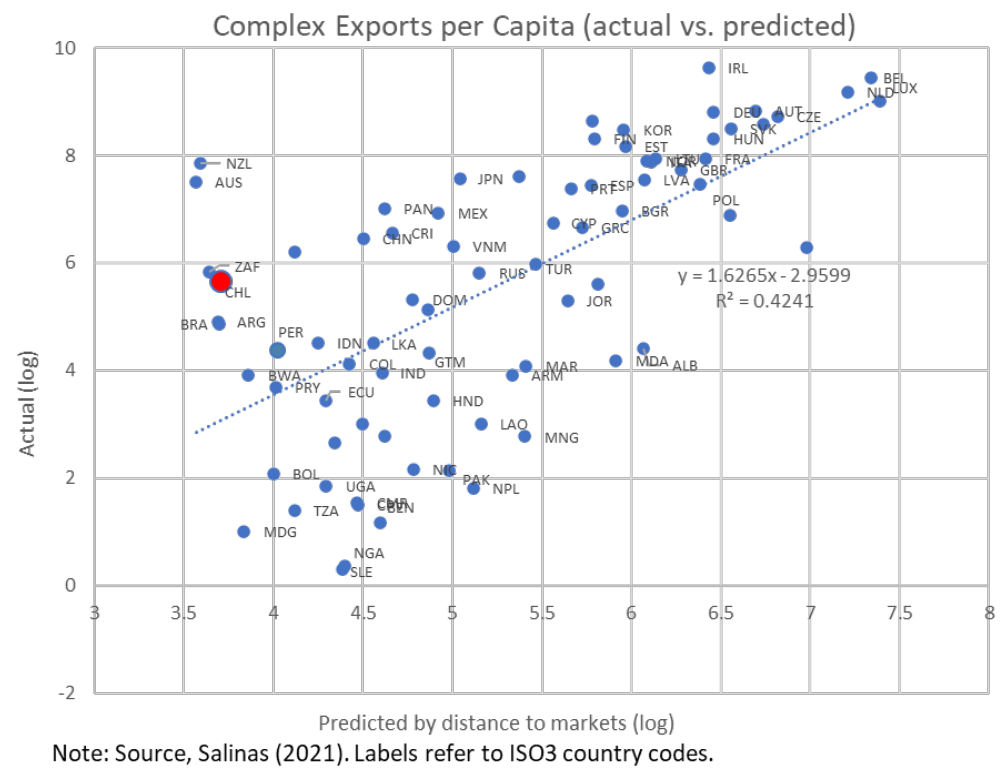

The world maps in Figure A.3 similarly indicate deviations from distance-predicted complex and NHM exports per capita. Countries in darker blue are those with higher upward deviation and those in darker red have higher downward deviation. In the case of complex exports, superlative countries include well known models of export development in East Asia, such as Japan, Malaysia, South Korea, and Thailand. Remarkably, the upward deviation of Chile's complex exports per capita with respect to the level predicted by distance is also among the highest in the world, as is the case for also remote Australia (AUS) and New Zealand (NZL). Chile's upward deviation in NHM exports per capita is even higher, reflecting its success in promoting some natural resource based products (fisheries, agroexports, forestries).

A scatter plot comparing the level of complex export per capita predicted by distance plus policy variables (governance, education, infrastructure, and import tariffs) does a much better job at predicting Chile's complex exports. This improvement in fit when adding policy variables strongly suggests that Chile's strong policy fundamentals considerably improve its complexity. 


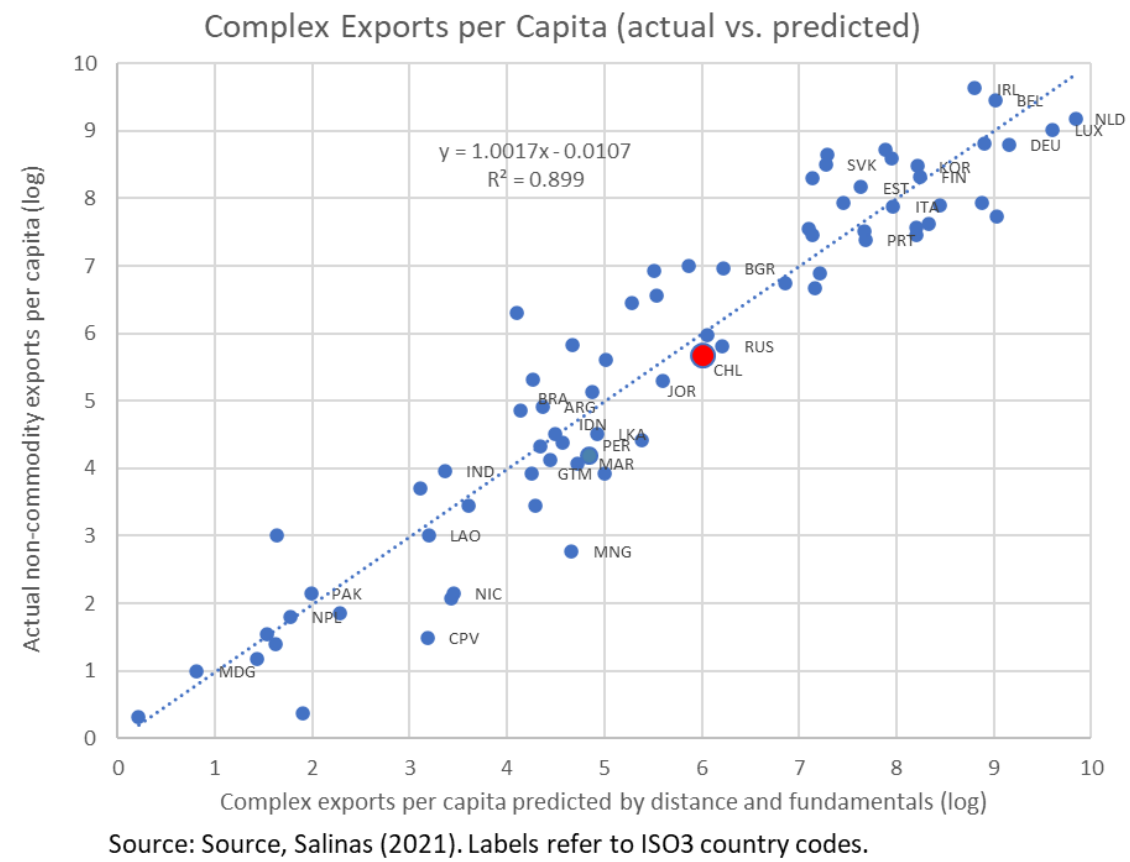

Acknowledging Chile's remoteness, its export promotion success is better judged by comparing it with other remote countries. Among a sample of remote countries included in the charts below, only Australia and New Zealand have exports complexity levels above the average in East Asian Emerging Market countries. Following these high income economies, Chile has the next highest level of per capita complex exports among these remote economies. ${ }^{13}$
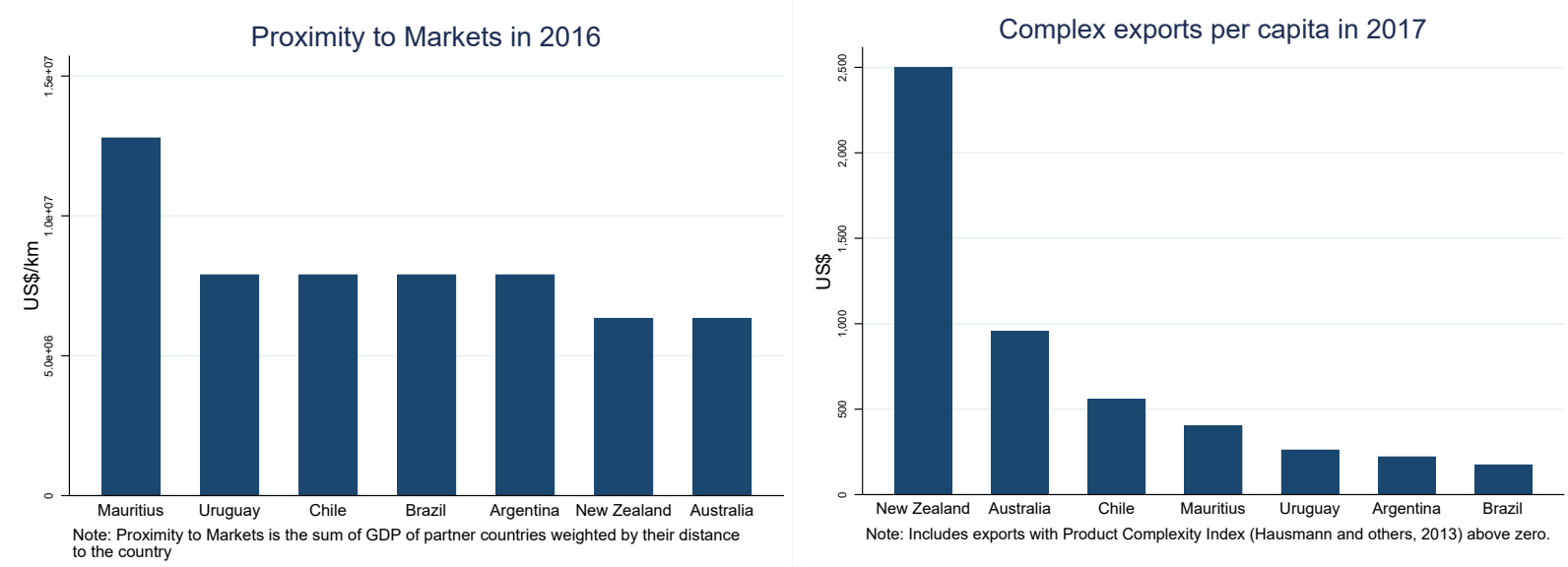

\footnotetext{
${ }^{13}$ The comparator remote countries include those with an income per capita above 8,000 US dollars per capita, population above 1 million, and located at a southern latitude similar to Chile's.
} 


\section{Export Diversification Determinants in Chile and Emerging Regions}

While Chile's export basket has historically been concentrated in copper exports, its NHM exports per capita was within the average range of EM regional groups already back in 1980 . Since then it has gradually surpassed the average level in most other EM regions, including the high performing EAEM region. Despite its remoteness to the large economic centers, Chile has better used its natural resource abundance in NHM products to surpass EAEM and SCC countries, even though these regions are also natural resource abundant. Its progress in fostering complex export development has not been as impressive, only surpassing SCC countries and lagging the EAEM average.

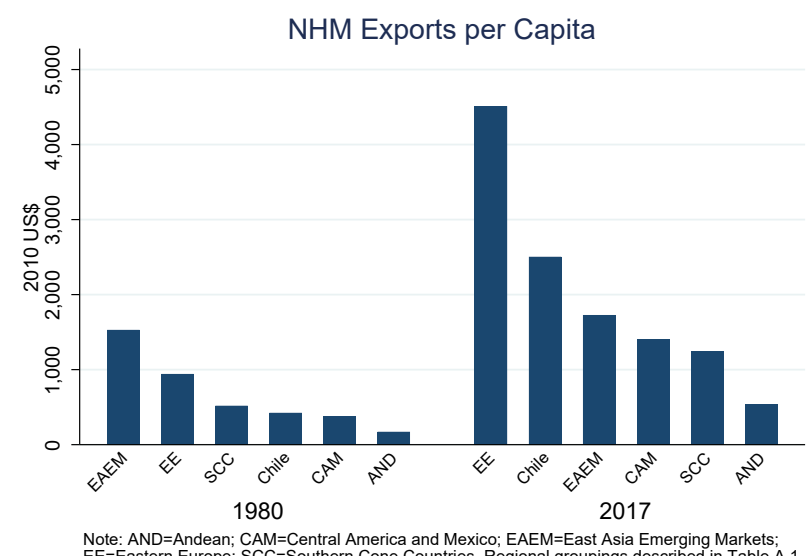

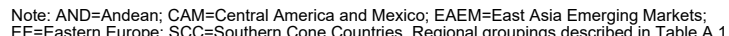

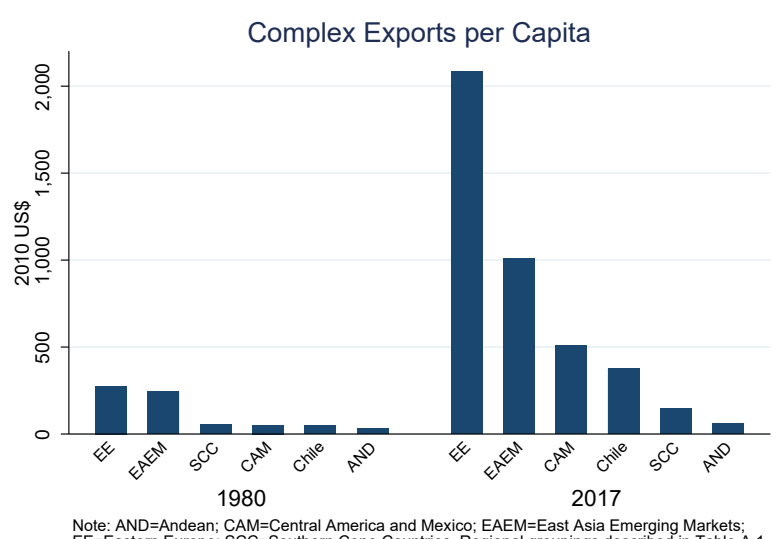

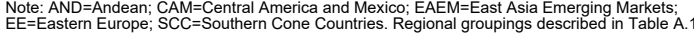

Chile's less impressive development of complex exports relative to EAEM is likely related to its remoteness, as these exports commonly develop within GVCs, which are strongly dependent on proximity to large economies. Interestingly, Chile's distance disadvantage relative to EAEM's has increased, as its PM index relative to this region decreased from two thirds in 1980 to one half in 2017. This is likely because the large East Asian economic agglomeration (efficiently linked through

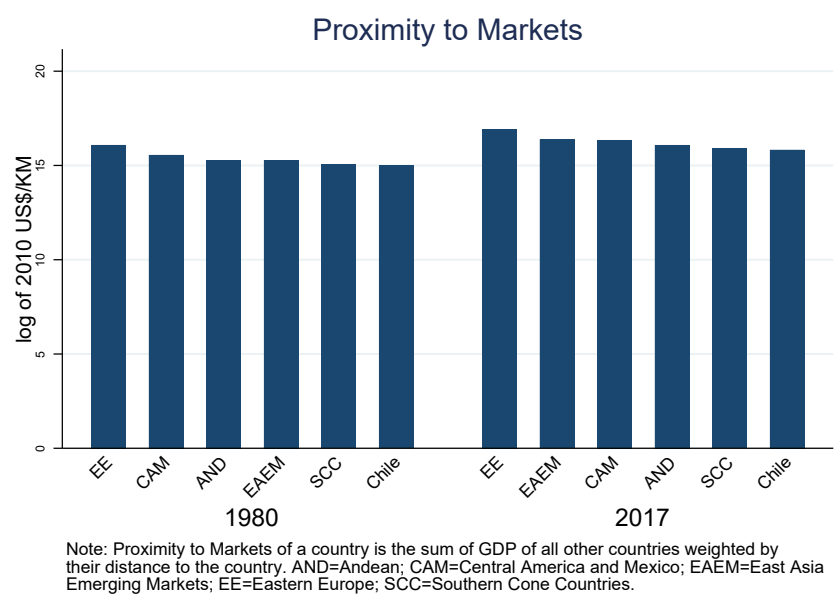
sea-based transportation) benefits from a virtuous circle through which the high initial PM of these countries fosters their intraregional exports and economic activity and this in turn increases the regions PM. As many of these countries still have significant room to converge to the income per capita of advanced countries this virtuous circle may be prolonged. 
In contrast, Chile's relatively isolated South American neighbors have low PM and this limits their potential for intraregional export development and economic growth. Without the impulse from a nearby and fast-growing economic agglomeration, Chile's development of non-copper exports has hinged on the strength of its policy determinants of export diversification and complexity.

An important area of progress has been the strengthening of political stability and governance. After a politically unstable period that included an almost two-decade long military government, Chile returned to a democratic system and experienced a long period of uninterrupted development of political and economic institutions. This is reflected in an improvement in its Polity IV index from a negative to the maximum score, same score as for Australia and New Zealand. And by 2017, the World Bank's

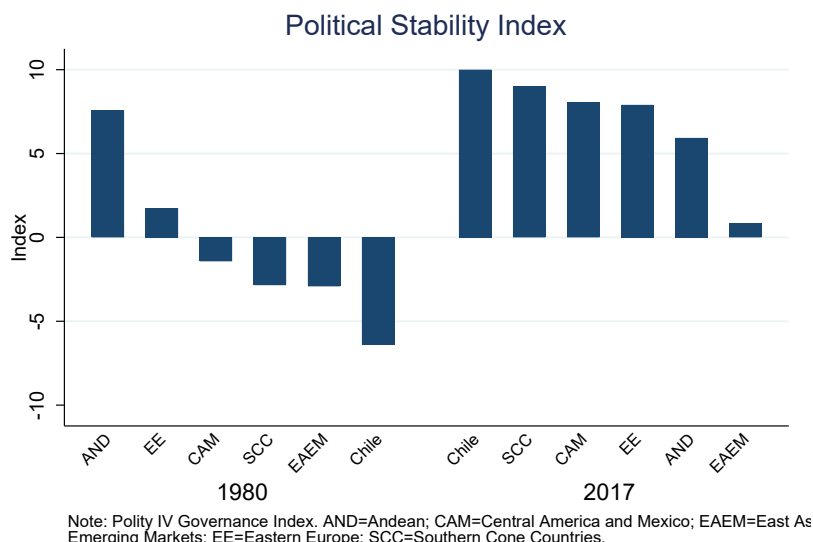
overall governance index indicates that Chile is considerably ahead the average in comparator EM country groups, as seen in Panel Figure A.4.

Chile's educational attainment has been an important contributor to its export's development for several decades. Although its educational attainment has been recently surpassed by the EE region, it remains above that of other EM regions, including EAEM. A comparison of its PISA test results with that of other EM countries indicates that the quality of education in Chile is similarly higher than in most other EM countries in Reading and Science, but it's at a less superior standing in Math. Nevertheless, Chile has significant

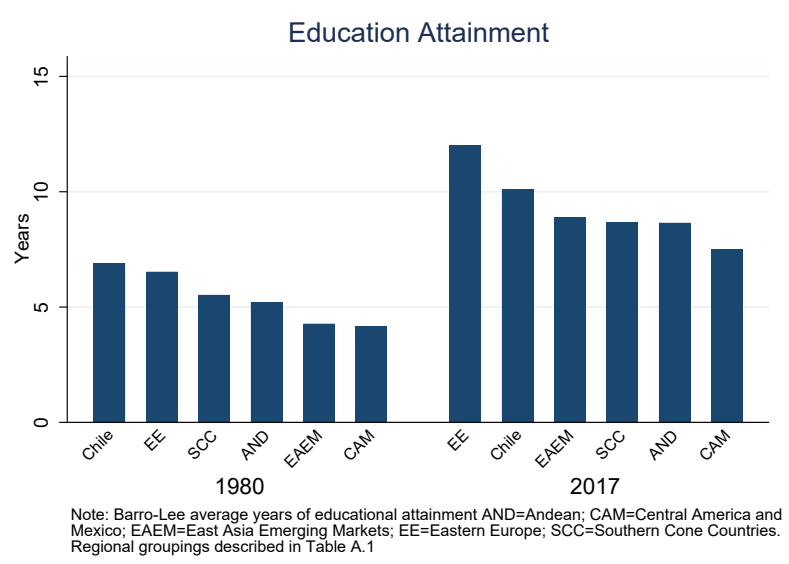
room to strengthen its education quality as pointed out in IMF (2021), with Chile being significantly below OECD countries in terms of both PISA tests and basic competencies. 
Chile's progress in liberalizing its trade policies has been particularly outstanding. Its average Most-Favored-Nation (MFN) tariff has been reduced from about 100 percent in the 1970 s to about 25 percent in 1980, and to low single-digit in 2017. This 95 percentage point reduction in Chile's average tariff on its own is statistically associated to a twenty-fold expansion in complex exports per capita according to estimates in Salinas (2021). Chile is also one of few countries that wiped out non-tariff barriers, and did it ahead of most developing countries, in the 1970s.

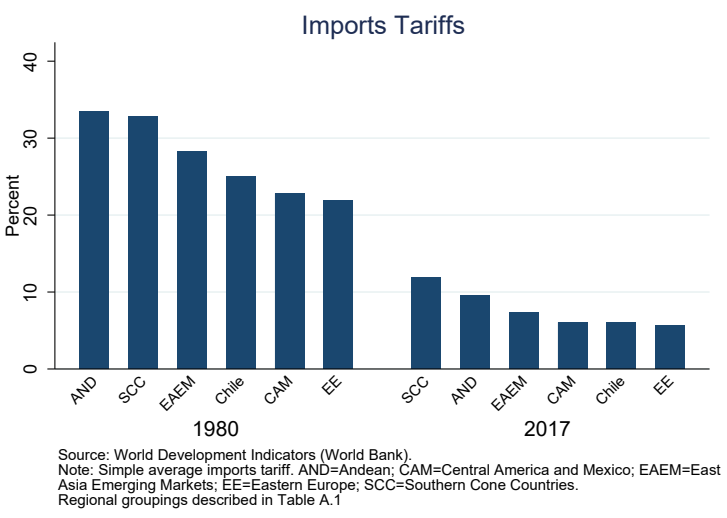
Moreover, Chile has been notably active in signing Free-Trade Agreements, especially with its largest trading partners, including the United States, East Asian countries, the European Union, Oceanian Countries, and other South American countries. Hence, most of Chile's exports and imports are subject to the open trade conditions established in these agreements.

Infrastructure coverage in Chile has rapidly expanded in recent decades and its quality is superlative in some areas. An index of infrastructure coverage that factors in electricity and phone line infrastructure going back to 1985 , shows that Chile's coverage has remained about average among EM regions but has closed the gap with respect to Eastern Europe. In addition, the Infrastructure Pillar of the Global Competitiveness Index (World Economic Forum), which factors in quality for a wider set of infrastructure areas, indicates that Chile infrastructure excels in most areas (see Panel Figure A.6). This is particularly the case on ports and electricity quality, identified in Salinas (2021) as the areas of infrastructure most strongly associated with export development.

In light of its geographic disadvantage Chile should aim to foster its exports diversification and complexity by strengthening its policy framework to reach Australia and New Zealand, remote countries that have successfully developed NHM and complex exports way above EE and EAEM countries. Except for trade policy openness, Chile has significant room to catch up with these two advance countries in all the other three factors associated with export development. 
According to regression analysis in Salinas (2021), strengthening these factors could increase Chile's complex exports subtantially. From these estimates it is infered that eliminating the significant gap in the education attaintment gap with respect to, for example, New Zealand is associated with 100 percent increase in complex exports. Eliminating the gap in governance and infrastructure relative to New Zealand could increase complex exports by 45 and 23 percent, respectively. And lowering average tariffs to New Zealand's level could increase complex exports by 13 percent. Attaining all these improvements would triple Chile's complex exports, considerably Chile Complex Exports per Capita in 2015-17 with New Zealand Policies

\begin{tabular}{lr} 
& US\$ \\
\hline Actual & 375 \\
& \\
Predicted with New Zealand Policies & \\
Governance & 545 \\
Educational attainment & 752 \\
Infrastructure quality & 461 \\
Average import tariff & 427 \\
Combined policies & 1531 \\
& \\
\hline
\end{tabular}

Source: UN Comtrade and author's calculations surpassing the average in EAEM although not attaining EE's average largely because of remoteness.

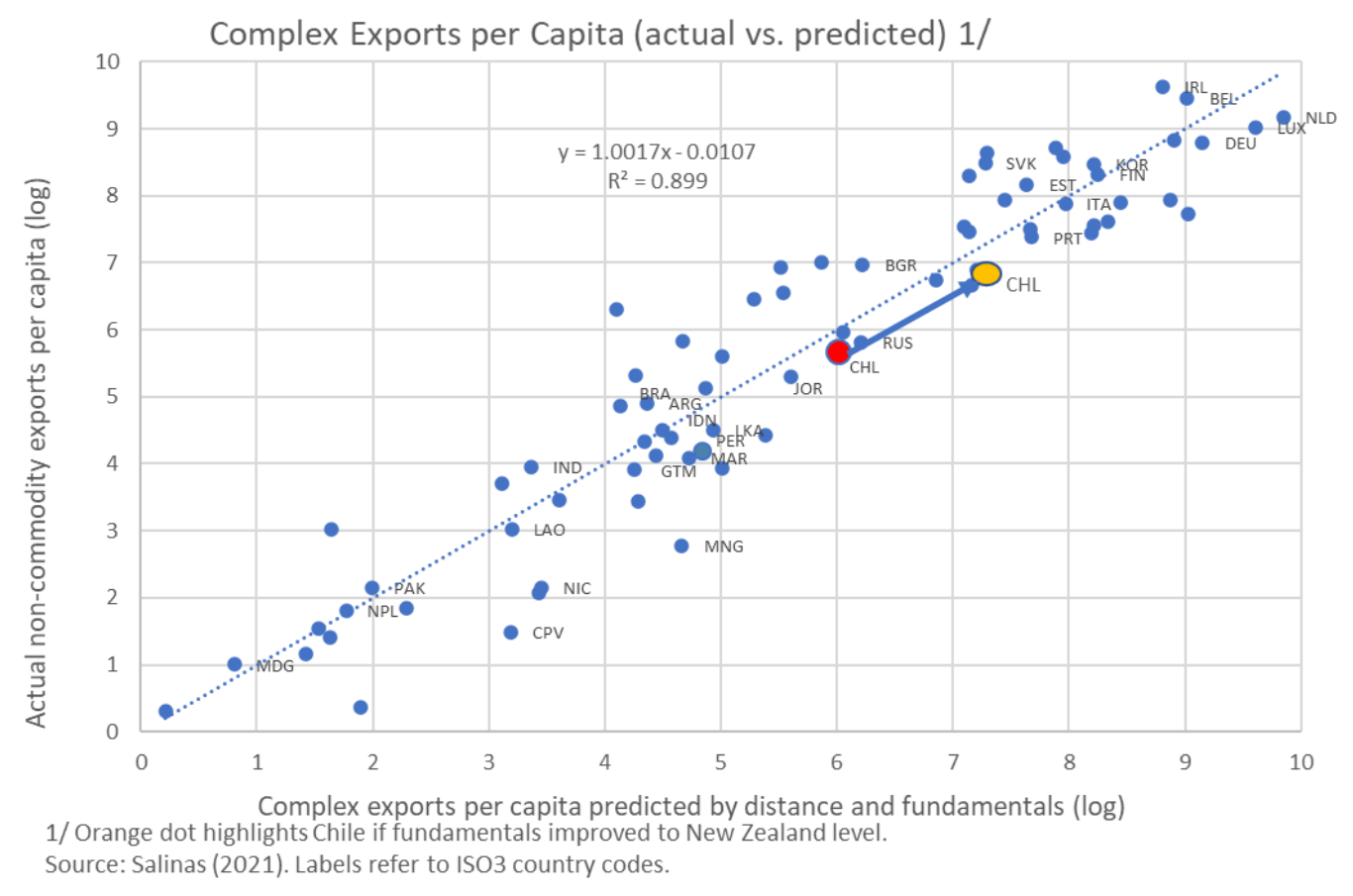

\section{E. Conclusions}

Chile's development of non-mineral and complex exports has been more successful than implied by commonly used diversification and complexity indices. When observing the level and long term growth of NHM and complex export categories, Chile's performance appears as strong as its overall economic performance and more similar to the average in the high performing East Asian region than to other South American countries. This has been the case despite Chile's remoteness from the large global economic centers and likely a result of its wellrecognized efforts to strengthen its institutional development, educational attainment, trade policy openness, and physical infrastructure. 
If Chile has low diversification and ranks low in terms of the ECI it is because of exogenous copper abundance and distance to large international markets, not because of an ineffective policy framework. In fact, among remote countries, Chile has seen the fastest growth in exports complexity per capita, owing to its strong performance on governance, education, infrastructure quality, and trade policy openness.

Going forward, this analysis underscores the need to preserve Chile's leadership in strengthening its economic fundamentals and redouble its efforts to overcome the hurdles imposed by distance to large markets. Australia and New Zealand are role models of high complexity development despite long distance from large international markets. With these countries and other advanced economies as benchmark, Chile should continue to strengthen governance, education, and infrastructure to reach higher degrees of complexity. Transports infrastructure is particularly important, as this can help reduce the cost imposed by remoteness.

Sectorally, Chile can focus on the development of exports of services and of high value-toweight products, which are less affected by transportation costs. Improving telecommunications and electricty infrastructure towards the quality level of advanced countries would be key to foster complex exports services. Technology will clearly be Chile's best ally in overcoming its distance hurdle. 


\section{References}

Barro, Robert J. and Lee, Jong Wha, 2013. "A new data set of educational attainment in the world, 1950-2010," Journal of Development Economics, Elsevier, vol. 104(C), pages 184-198, retrieved from: < http://www.barrolee.com/ $>$.

Cadestin, C., J. Gourdon and P. Kowalski, 2016, "Participation in Global Value Chains in Latin America: Implications for Trade and Trade-Related Policy," OECD Trade Policy Papers 192, OECD Publishing.

Ding, Xiaodan and Metodij Hadzi-Vaskov, 2017, "Composition of Trade in Latin America and the Caribbean," IMF Working Papers 2017/042, International Monetary Fund.

Eaton, J. and S. Kortum, 2002, "Technology, Geography, and Trade," Econometrica, Econometric Society, vol. 70(5), pages 1741-1779.

Giri, Rahul, Saad N Quayyum, Rujun Yin, 2019, "Understanding Export Diversification: Key Drivers and Policy Implications," IMF Working Papers 19/105, International Monetary Fund.

Haddad, Mona, Jamus Jerome Lim, Cosimo Pancaro and Christian Saborowski, 2012, “Trade openness reduces growth volatility when countries are well diversified," ECB Working Paper No. 1491.

Hausmann, Ricardo, Jason Hwang and Dani Rodrik, 2006, "What You Export Matters," CEPR Discussion Papers 5444, C.E.P.R. Discussion Papers.

Hausmann, Ricardo, César A. Hidalgo, Sebastián Bustos, Michele Coscia, Alexander Simoes, Muhammed A. Yildirim, 2013, "The Atlas of Economic Complexity: Mapping Paths to Prosperity," The MIT Press.

Hidalgo, Cesar and Ricardo Hausmann, 2009, "The Building Blocks of Economic Complexity," Proceedings of the National Academy of Sciences of the United States of America, 106 (26), pp. $10570-10575$.

Hnatkovska, Viktoria V. and Norman Loayza, 2004, "Volatility and growth," Policy Research Working Paper Series 3184, The World Bank.

International Monetary Fund, 2021, 2021 Article IV Consultation-Press Release; Staff Report; and Statement by the Executive Director for Chile, IMF Country Report No. 21/83, Washington, DC.

Lebdioui, Amir, 2019. "Chile's export diversification since 1960: A free market miracle or mirage?," LSE Research Online Documents on Economics 101885, London School of Economics and Political Science, LSE Library. 
OECD, 2018, Trade in Value added. Available at http://www.oecd.org/sti/ind/measuring-tradein-value-added.htm

Polity IV, 2014, Polity IV Project, Severn, Maryland: Center for Systematic Peace. Retrieved from: http://www.systemicpeace.org/polity/polity $4 . h$ tm.

Raei, Faezeh, Anna Ignatenko, Borislava Mircheva, 2019, "Global Value Chains: What are the Benefits and Why Do Countries Participate?," IMF Working Papers 2019/018, International Monetary Fund.

Ramey, Garey and Valerie A. Ramey, 1995, "Cross-Country Evidence on the Link Between Volatility and Growth," The American Economic Review, Vol. 85, No. 5 (Dec., 1995), pp. 11381151.

Salinas, Gonzalo, 2021, "Proximity and Horizontal Policies: The Backbone of Export Diversification”, IMF Working Paper WP/21/64, Washington, DC.

United Nations, 2020, UN Comtrade. Available at $<$ http://comtrade.un.org $>$.

United Nations Development Program, 2020, Human Development Reports, Various editions, retrieved from: http://hdr.undp.org/en/content/education-index.

Weldemicael, Ermias O., 2012, "Determinants of Export Sophistication," The University of Melbourne, available at https://www.business.unsw.edu.au/About-Site/Schools-Site/EconomicsSite/Documents/E. Weldemicael $\% 20-\% 20$ Determinants $\% 20$ of $\% 20$ Export $\% 20$ Sophistication.pdf

World Bank, 2020a, Worldwide Governance Indicators, various editions, World Bank Publications, World Bank, Washington DC, retrieved from:

$<$ https://info.worldbank.org/governance/wgi/>.

World Bank, 2020b, World Integrated Trade Solution, various editions, World Bank, Washington DC, retrieved from: https://wits.worldbank.org/.

World Economic Forum, and Harvard University, 2020, The Global Competitiveness Report, various editions, Geneva: World Economic Forum, retrieved from:

https://www.weforum.org/reports/the-global-competitiveness-report-2020. 
Table A.1

\begin{tabular}{|c|c|c|c|c|c|c|c|c|}
\hline Region & Region Code & Courtry & Region & Region Code & Country & Region & Region Code & Country \\
\hline \multirow{5}{*}{ Andean } & AND & Bolivia & Eastern & $\mathrm{EE}$ & Albania & Pacific Isl. & PAC & Tonga \\
\hline & & Colombia & Europe & & Bosnia Herz. & & & Tuvalu \\
\hline & & Ecuador & & & Bulgaria & & & Vanuatu \\
\hline & & Peru & & & Croatia & South Asia & SAR & Afgharistan \\
\hline & & Venezuela & & & Cyprus & & & B angladesh \\
\hline \multirow[t]{8}{*}{ Arab } & ARB & Bahrain & & & Czechia & & & Bhutan \\
\hline & & Brunei & & & Estonia & & & Nepal \\
\hline & & Kuwait & & & Georgia & & & Pakistan \\
\hline & & Oman & & & Hungary & & & Sri Lanka \\
\hline & & Qatar & & & Latvia & & & Timor-Leste \\
\hline & & Saudi Arabia & & & Lithuania & Southern & $\mathrm{SCC}$ & Argentina \\
\hline & & $\mathrm{UAE}$ & & & Montenegro & Cone & & Brazil \\
\hline & & Yemen & & & N. Macedonia & & & Chile \\
\hline \multirow[t]{8}{*}{ Central Asia } & $\mathrm{CA}$ & Armenia & & & Poland & & & Paraguay \\
\hline & & Azerbaijan & & & Mol dova & & & Urugray \\
\hline & & Belarus & & & Romania & Scandinavia & $\mathrm{SCN}$ & Denmark \\
\hline & & Kazakhstan & & & Russia & & & Finland \\
\hline & & Kyrgyzstan & & & Serbia & & & Iceland \\
\hline & & Tajikistan & & & Serb. and Mort. & & & Norway \\
\hline & & Turkmeristan & & & Slovakia & & & Sweden \\
\hline & & Uzbekistan & & & Slovenia & Sub- & SSA & Angola \\
\hline \multirow{7}{*}{$\begin{array}{l}\text { Central Am. } \\
\text { \& Mexico }\end{array}$} & $\mathrm{CAM}$ & Costa Rica & & & Tưkey & Saharan & & Benin \\
\hline & & E1 Salvador & & & Ukraine & Africa & & Botswana \\
\hline & & Guatemala & European & $\mathrm{EU}$ & Andorra & & & Burkina Faso \\
\hline & & Honduras & Union & & Austria & & & Burundi \\
\hline & & Mexico & & & Belgium & & & Cabo Verde \\
\hline & & Nicaragun & & & France & & & Cameroon \\
\hline & & Panama & & & Germany & & & Central African Rep. \\
\hline \multirow{24}{*}{ Caribbean } & CAR & Anguilla & & & Greece & & & Chad \\
\hline & & Antig \& Barb. & & & Greenl and & & & Comoros \\
\hline & & Aruba & & & Ireland & & & Congo \\
\hline & & Bahamas & & & Italy & & & Cote divoire \\
\hline & & Barbados & & & Lux embourg & & & D.R. Congo \\
\hline & & Belize & & & Malta & & & Djibouti \\
\hline & & Bermuda & & & Netherlands & & & Eritrea \\
\hline & & Cayman Isds & & & Portugal & & & Ethiopia \\
\hline & & Cuba & & & Spain & & & Gabon \\
\hline & & Dominica & & & Switzerland & & & Gambia \\
\hline & & Dominican Rep. & & & U.K & & & Ghana \\
\hline & & French Guiana & India & IND & India & & & Guinea \\
\hline & & Grenada & Middle East & $\mathrm{ME}$ & Iran & & & Guinea-Bissau \\
\hline & & Guadeloupe & & & Iraq & & & Kenrya \\
\hline & & Guyana & & & Israel & & & Lesotho \\
\hline & & Haiti & & & Jor dan & & & Liberia \\
\hline & & Jamaica & & & Lebanon & & & Madagascar \\
\hline & & Martinique & & & Syria & & & Malawi \\
\hline & & Montserrat & North Africa & $\mathrm{NA}$ & Algeria & & & Mali \\
\hline & & St Kitts \& Nevis & & & Egypt & & & Mauritania \\
\hline & & Saint Lucia & & & Libya & & & Mauritius \\
\hline & & St Vct \& Gren & & & Morocco & & & Mayotte \\
\hline & & Suriname & & & Tunisia & & & Mozambique \\
\hline & & Trini dad \& Tob. & North & NAM & Canada & & & Namibia \\
\hline East Asia & EAEM & China & America & & USA & & & Niger \\
\hline \multirow[t]{6}{*}{ Emerging } & & China, Macao SAR & Oceania & OCE & Australia & & & Nigeria \\
\hline & & Indonesia & & & New Zealand & & & Rwanda \\
\hline & & Malaysia & Pacific Isl. & PAC & Cook Isds & & & Sao Tome \& Princ. \\
\hline & & Philippines & & & FS Micronesia & & & Seneggl \\
\hline & & Thailand & & & Faeroe Isds & & & Seychelles \\
\hline & & Viet Nam & & & $\mathrm{Fiji}_{\mathrm{ij}}$ & & & Sierra Leone \\
\hline \multirow{4}{*}{$\begin{array}{l}\text { East Asia } \\
\text { High Income }\end{array}$} & EAHI & China, Hong Kong & & & French Polynesia & & & Somalia \\
\hline & & Japan & & & Kiribati & & & South Africa \\
\hline & & Singapore & & & Maldives & & & Sudan \\
\hline & & South Korea & & & New Caledonia & & & Togo \\
\hline \multirow{4}{*}{$\begin{array}{l}\text { East Asia } \\
\text { Others }\end{array}$} & EAOTH & Cambodia & & & Palau & & & Uganda \\
\hline & & Lao PDR & & & Pap. New Gn & & & Tanzania \\
\hline & & Mongolia & & & Samoa & & & Zambia \\
\hline & & Myarmar & & & Solomon Isds & & & Zimbabwe \\
\hline
\end{tabular}




\section{Panel Figure A.1}

\section{Complex Exports per Capita in Chile and Comparators}
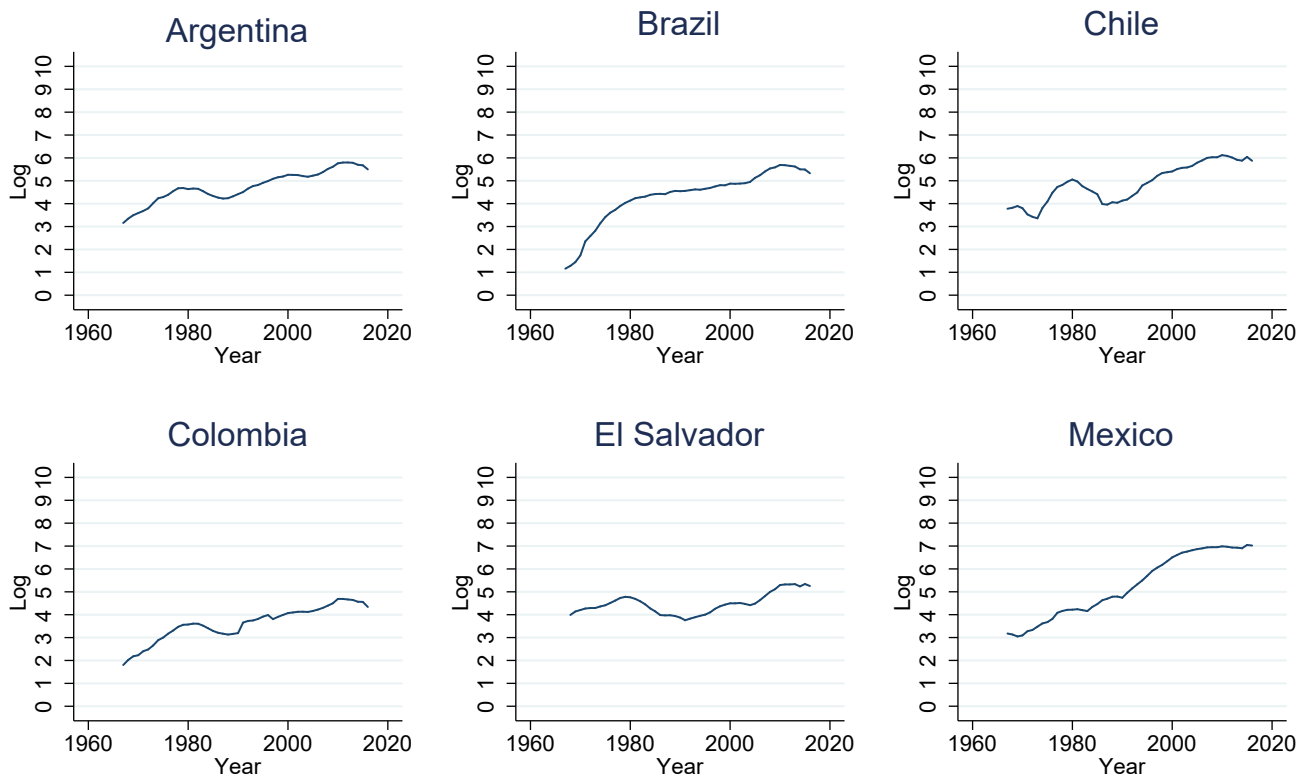

Note: Complex exports are goods with Product Complexity Index (Hausmann and others (2013) above zero. 


\section{Table A.2}

\begin{tabular}{|c|c|c|c|c|c|c|c|}
\hline Regression specification & $\begin{array}{l}\text { Hausman- } \\
\text { Taylor }\end{array}$ & $\begin{array}{l}\text { Hausman- } \\
\text { Taylor }\end{array}$ & $\begin{array}{c}\text { Hausman- } \\
\text { Taylor }\end{array}$ & Pooled OLS & $\begin{array}{c}\text { Between } \\
\text { Effects }\end{array}$ & $\begin{array}{l}\text { Random } \\
\text { Effects }\end{array}$ & Fixed Effects \\
\hline Log GDP reporter & $0.756^{* * *}$ & $0.484 * * *$ & $0.756^{* * *}$ & $1.354 * * *$ & $1.345 * * *$ & $1.369 * * *$ & $-0.548 * * *$ \\
\hline Log GDP partner & $0.858 * * *$ & $0.960^{* * *}$ & $0.858^{* * *}$ & $0.920 * * *$ & $0.904 * * *$ & $0.925 * * *$ & $0.347^{* * *}$ \\
\hline Log distance & $-1.279^{* * *}$ & $-0.616^{* * *}$ & $-1.279^{* * *}$ & $-1.420^{* * *}$ & $-1.444 * * *$ & $-1.465^{* * *}$ & \\
\hline Common currency dummy & 0.22 & $0.368^{* *}$ & 0.22 & $-0.193 *$ & -0.27 & -0.01 & \\
\hline Common border dummy & $1.888^{* * *}$ & $2.999 * * *$ & $1.888^{* * *}$ & $1.308^{* * *}$ & $1.327 * * *$ & $1.260 * * *$ & \\
\hline Common language dummy & $0.617 * * *$ & $0.899 * * *$ & $0.617 * * *$ & $0.676^{* * *}$ & $0.773 * * *$ & $0.638 * * *$ & \\
\hline Common colonizer dummy & $0.339 * *$ & $0.327 * *$ & $0.339 * *$ & $0.602 * * *$ & $0.561 * * *$ & $0.444 * * *$ & \\
\hline Past colonial link dummy & $1.228 * * *$ & $1.309^{* * *}$ & $1.228 * * *$ & $0.526^{* * *}$ & $0.482 * * *$ & $0.790 * * *$ & \\
\hline Log GDP per capita & -0.15 & -0.04 & -0.15 & $-0.918 * * *$ & $-0.973 * * *$ & $-0.680 * * *$ & $0.866^{* * *}$ \\
\hline Governance (WB Index) & $0.484 * * *$ & $0.422 * * *$ & $0.484 * * *$ & $0.634 * * *$ & $0.505^{* * *}$ & $0.789 * * *$ & $0.099 *$ \\
\hline Education (UN Index) & $5.099^{* * *}$ & $3.924 * * *$ & $5.099 * * *$ & $1.166^{* * *}$ & $1.498^{* * *}$ & $0.799 * * *$ & $1.031^{* *}$ \\
\hline Infrastructure (GCR Index) & $0.175^{* * *}$ & $0.166^{* * *}$ & $0.175^{* * *}$ & $0.694 * * *$ & $0.864 * * *$ & $0.307 * * *$ & $0.113^{* * *}$ \\
\hline Average Tariff & $-0.0310^{* * *}$ & $-0.0304 * * *$ & $-0.0310 * * *$ & $-0.0722 * * *$ & $-0.0784 * * *$ & $-0.0421 * * *$ & $-0.0197 * * *$ \\
\hline Labor market flexiblity (GCR Index) & 0.02 & 0.04 & 0.02 & $-0.334 * * *$ & $-0.374 * * *$ & -0.04 & 0.03 \\
\hline \multirow[t]{2}{*}{ Constant } & -0.86 & $-19.34 * * *$ & -0.86 & $-11.67 * * *$ & $-12.17 * * *$ & $-11.28 * * *$ & $-7.223 * *$ \\
\hline & $(-0.27)$ & $(-14.50)$ & $(-0.27)$ & $(-13.71)$ & $(-8.86)$ & $(-9.76)$ & $(-3.00)$ \\
\hline Partner country policy variables & No & Yes & Yes & Yes & Yes & Yes & Yes \\
\hline Multilateral resistance proxies & No & No & Yes & Yes & Yes & Yes & Yes \\
\hline Observations & 44,989 & 44,989 & 44,989 & 44,989 & 44,989 & 44,989 & 44,989 \\
\hline Rho & 0.93 & 0.94 & 0.93 & & & 0.81 & 0.94 \\
\hline
\end{tabular}

\section{CInternational Monetary Fund. Not for Redistribution}




\section{Panel Figure A.2: Marginal Contributions of Complexity Determinants}
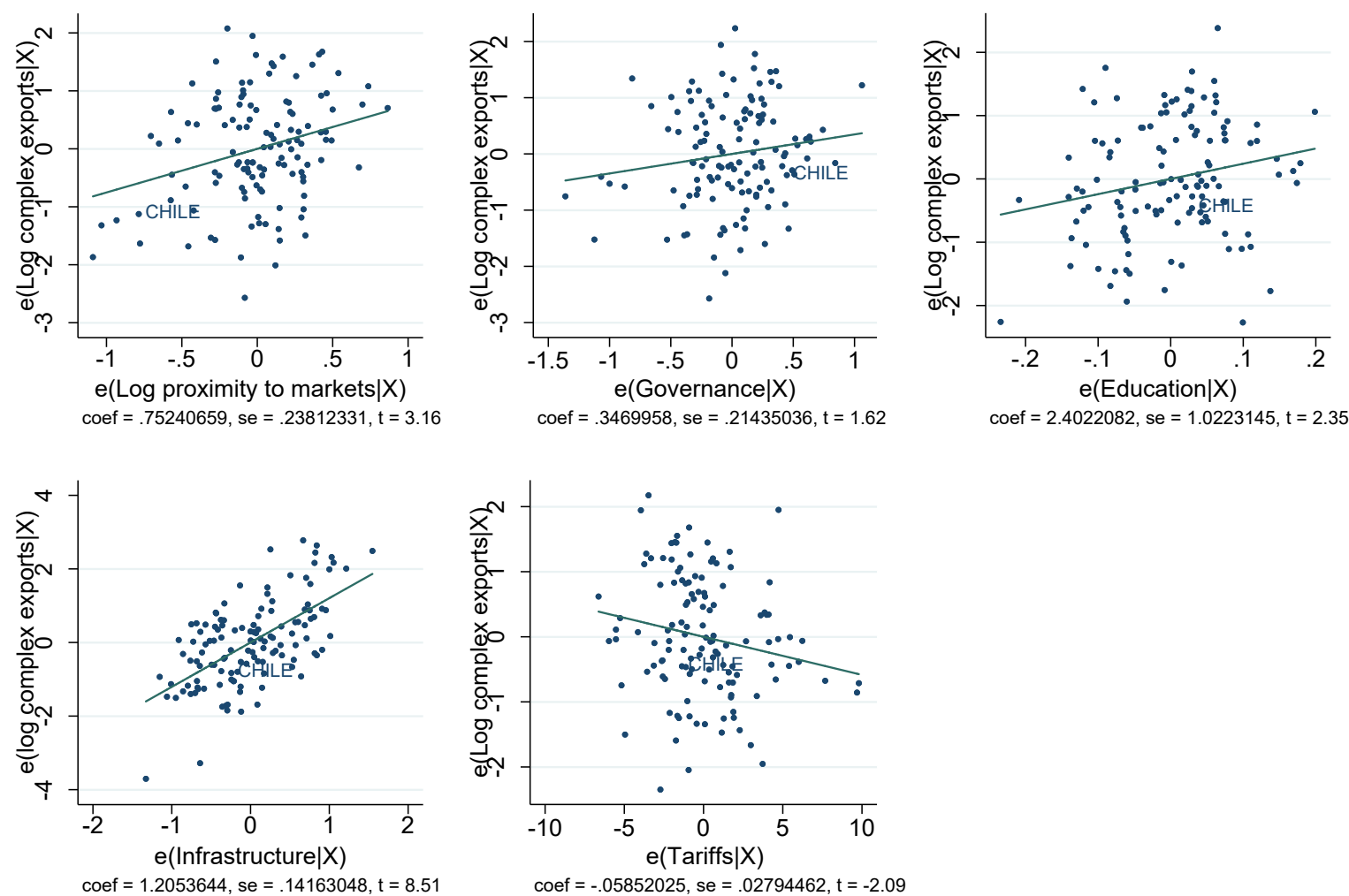

Note: Complex exports defined as products with Product Complexity Index above zero. 
Panel Figure A.3: Outliers of NHM and Complex Exports per Capita

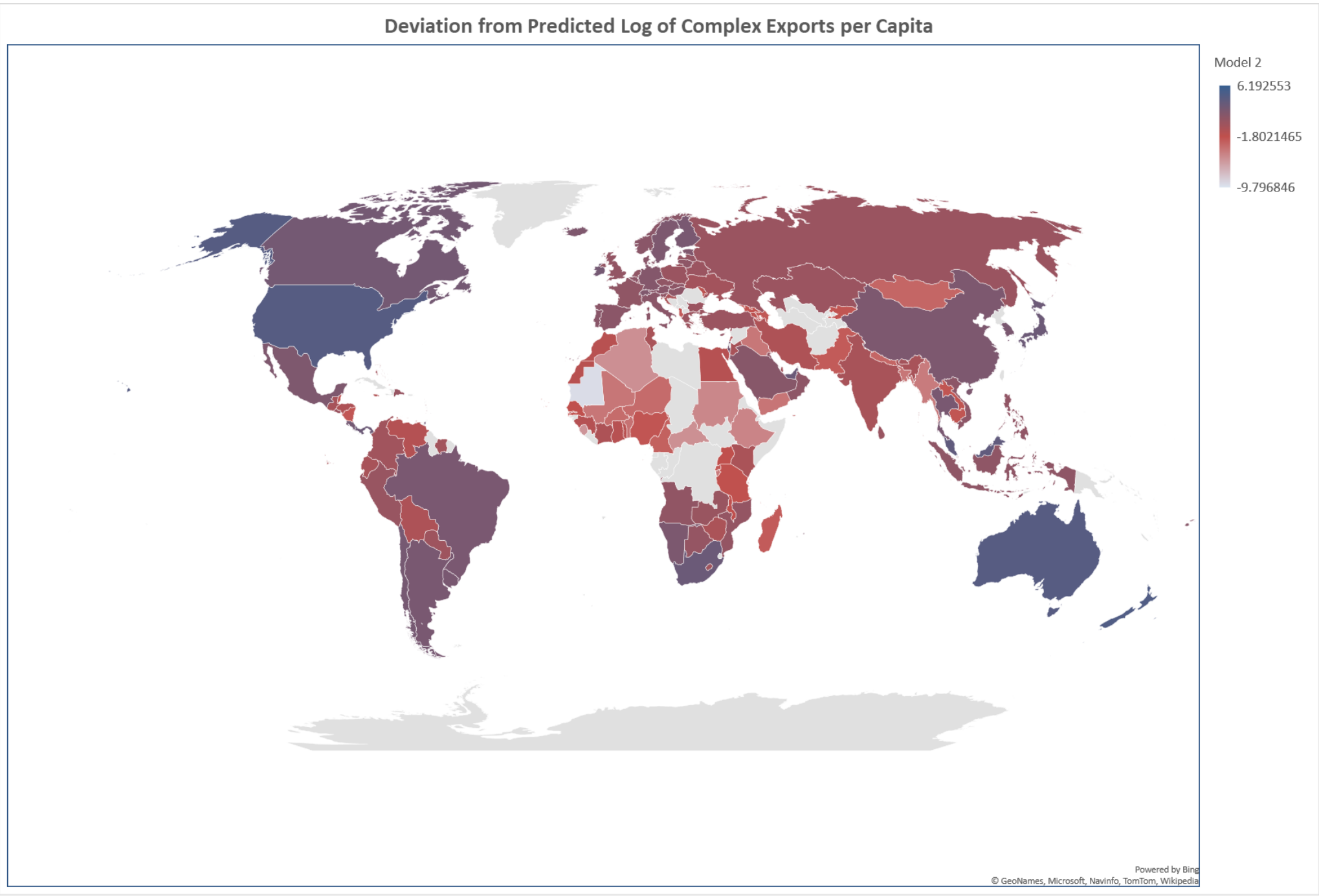

Source: Salinas (2021) 


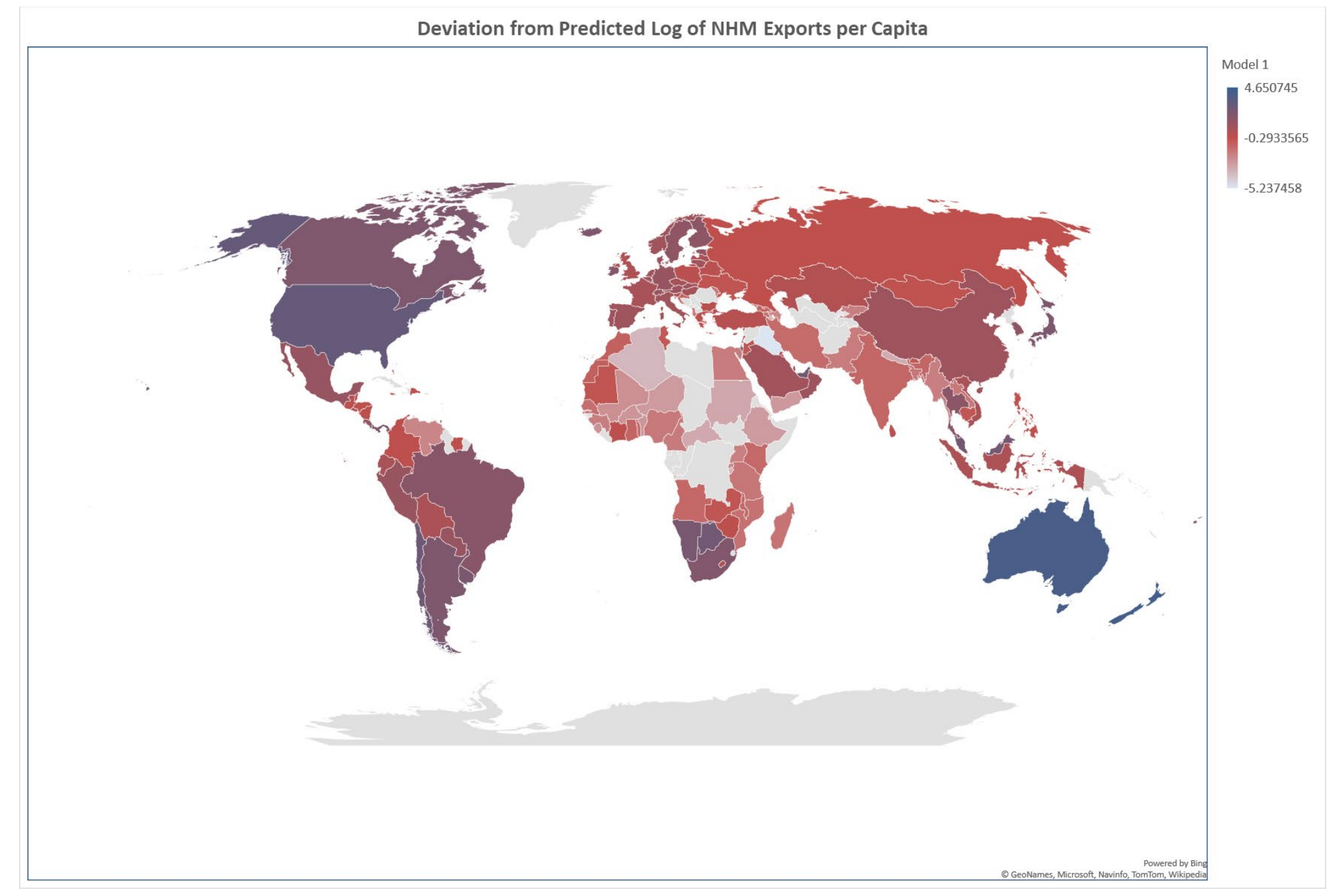

Source: Salinas (2021) 


\section{Panel Figure A.4: Determinants of Export Development in Chile and Comparator Countries}

Determinants of Complex Exports in Chile and Comparators in 2017
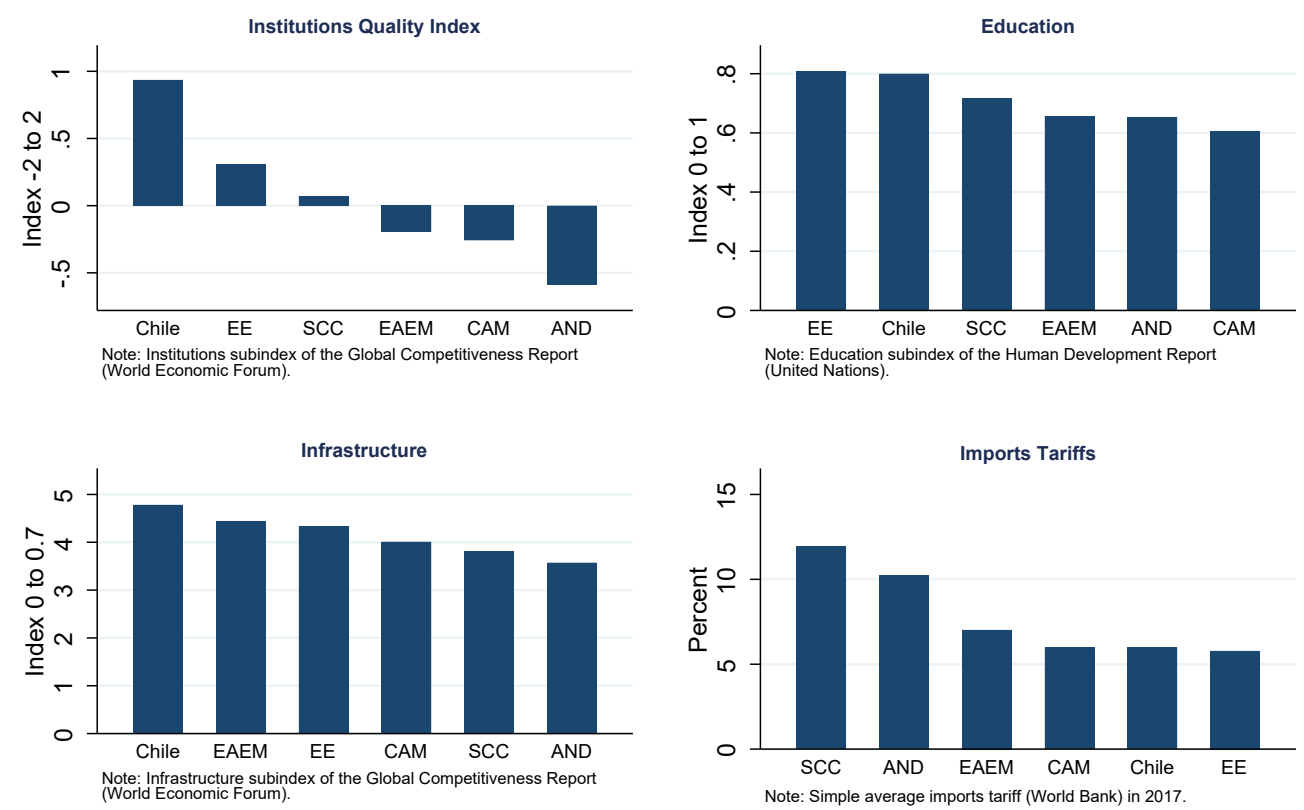

Note: $A N D=A n d e a n ; C A M=C e n t r a l$ America and Mexico; $E A E M=E a s t$ Asia Emerging Markets;

$\mathrm{EE}=$ Eastern Europe; $\mathrm{SCC}=$ Southern Cone Countries. Regional groupings described in Table A. 1 
Panel Figure A.5: Educational Quality in Chile and Comparators PISA tests by area
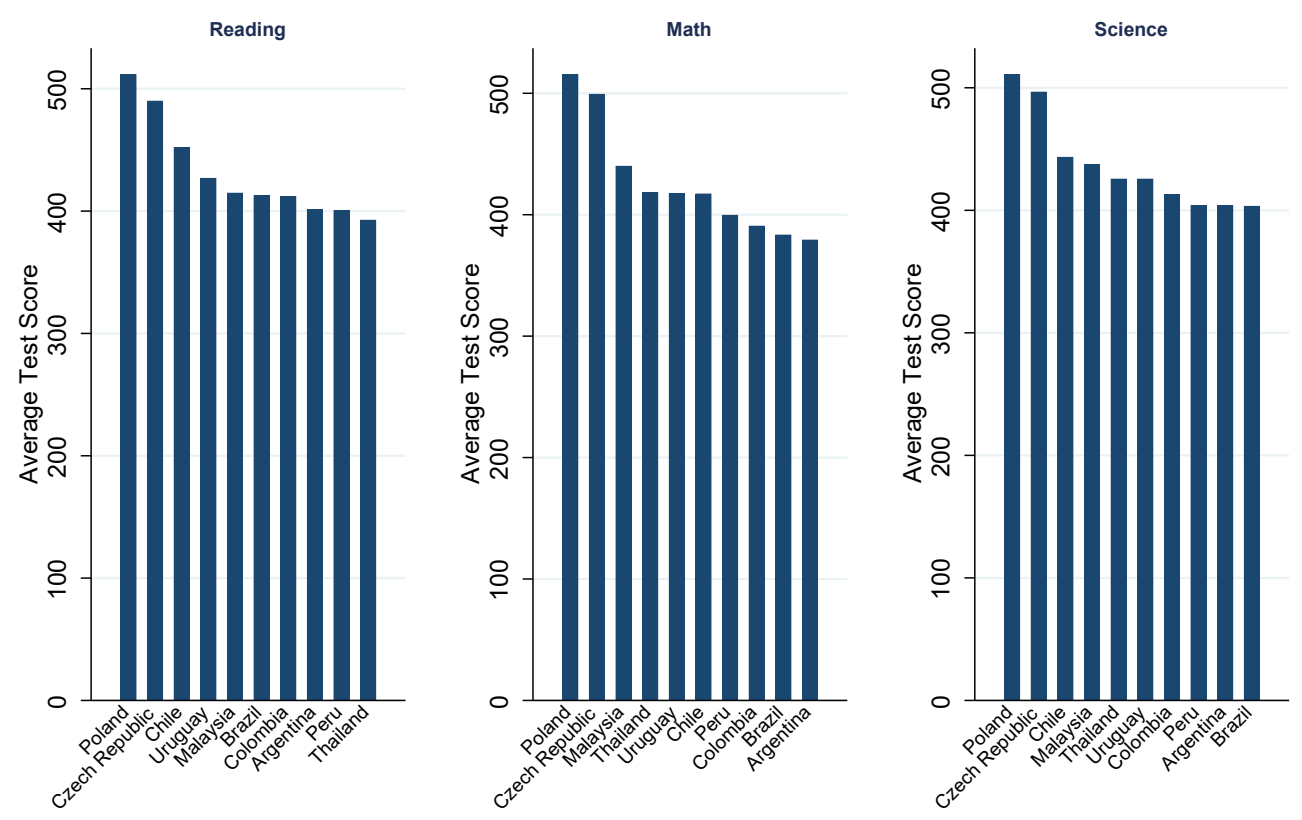

Source: OECD, PISA 2018 Database. 


\section{Panel Figure A.6: Infrastructure Indicators in Chile and Comparators}

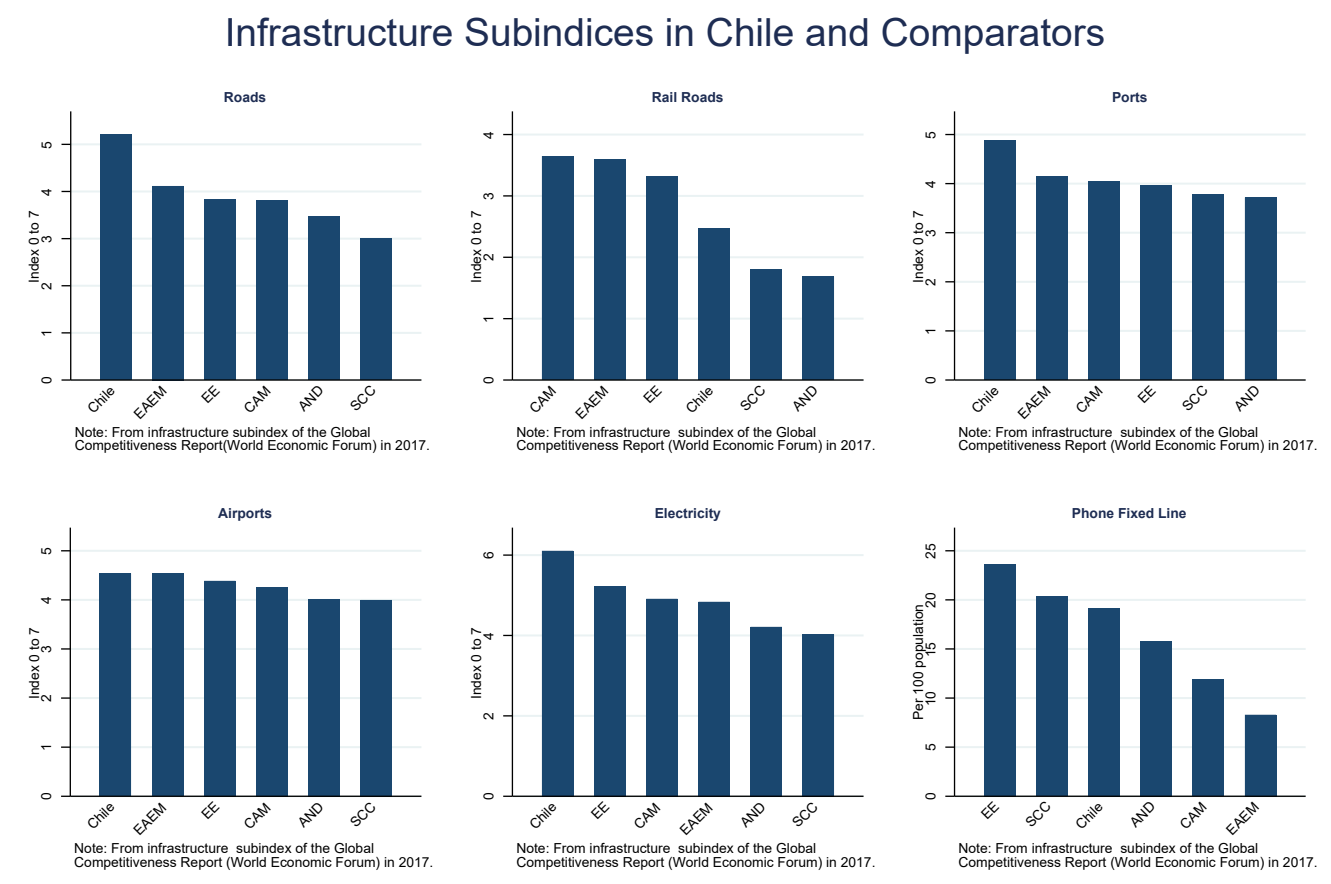

Note: $A N D=A n d e a n ; C A M=C e n t r a l$ America and Mexico; EAEM=East Asia Emerging Markets;

$\mathrm{EE}=$ Eastern Europe; SCC=Southern Cone Countries. Regional groupings described in Table A.1 


\section{Panel Figure A.7: Key Policy Intervention behind the emergence of Chile's Non-mining Sectors}

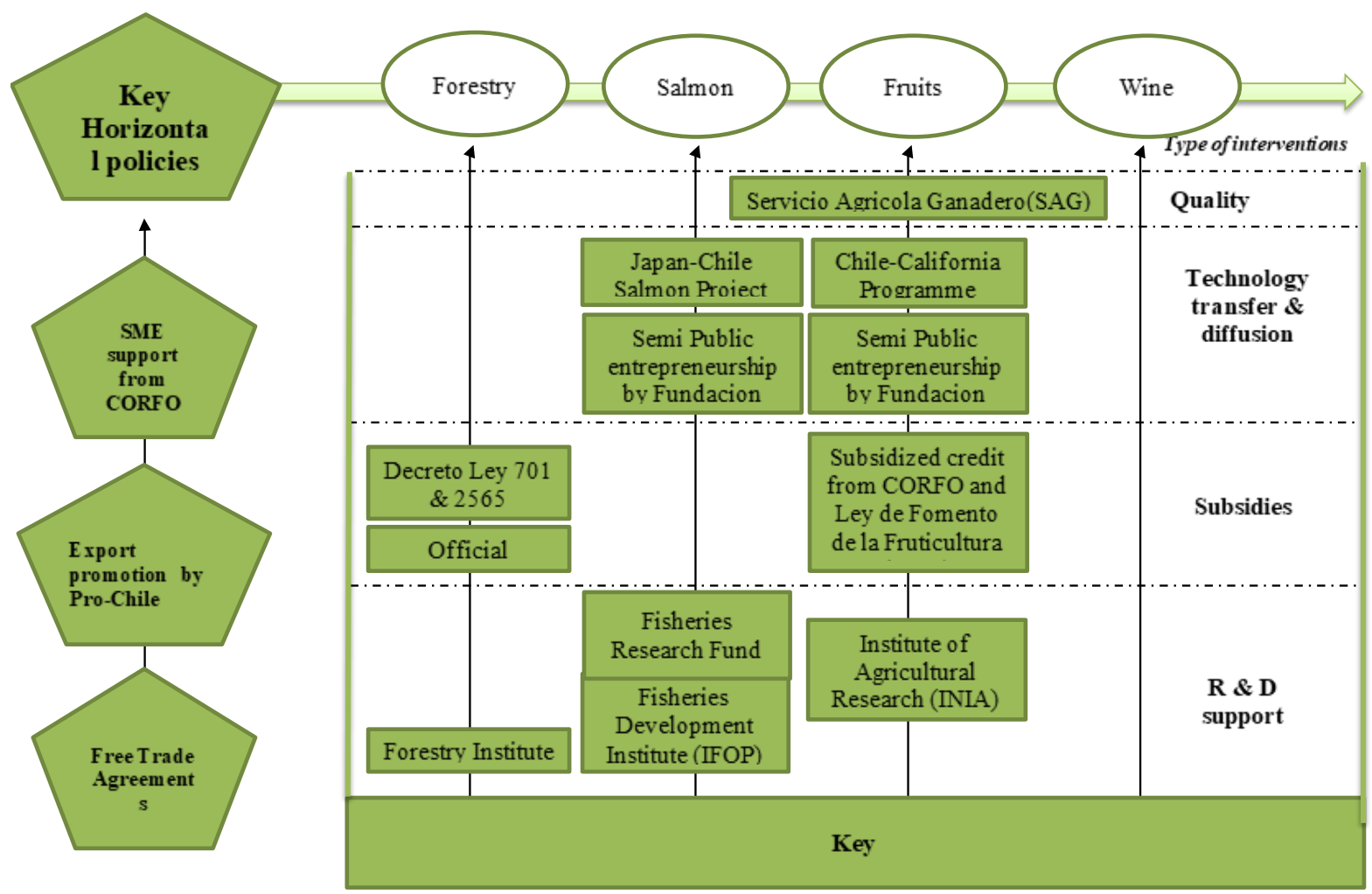

Source: Lebdioui (2019) 